Ohio Department of Development

Coal Development Office

Grant Agreement CDO/D-931-10

(Period of Performance - 4/1/94 to 3/31/97)

OCDO- 98081963
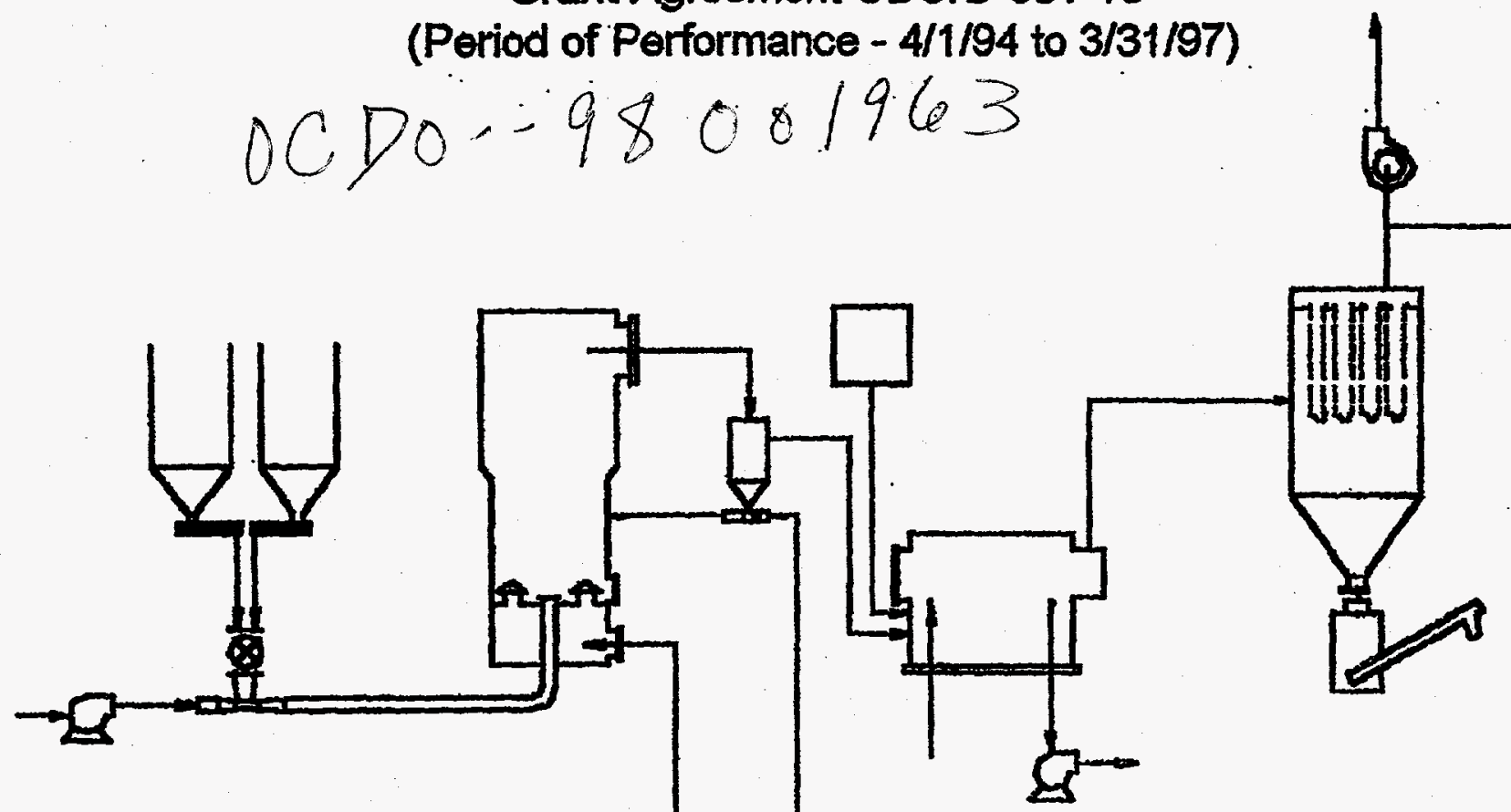

\title{
Atmospheric Fluidized Bed Combustion
}

for Small Scale Market Sectors

\section{Final Report}

\{This report contains no trade secret information\}

Prepared by:

Energy and Environmental Research Corporation

PO Box 153

Orville, Ohio 44667

Phone (330) 682-4007

Fax (330) 684-2110

ESTRIBUTION OF THIS DOCUMENT IS UNLIMTTED 


\section{DISCLAIMER}

Portions of this document may be illegible electronic image products. Images are produced from the best available original document. 
This project was funded in part by the Ohio Coal Development Office, Department of Development, State of Ohio.

OCDO Program Manager - Richard S. Chu

Project Manager for EER - Robert A. Ashworth, Manager - Advanced Systems

\section{ACKNOWLEDGMENTS}

The Energy and Environmental Research Corporation (EER) wish to express appreciation to the project sponsors, their managers and the host site personnel at Cedar Lane Farms, Inc. for the assistance received in completing this project, with special appreciation to the following:

Ohio Coal Development Office:

- Ms. Jacqueline Bird

- Mr. Howard Johnson

- Mr. Richard Chu

- Ms. Kathi Jones

United States Department of Energy: - Mr. Arthur W. Hall

- Ms. Denise Riggi

Ohio Agricultural Research and Development Center (OARDC):

- Dr. Thomas Payne

- Dr. Ted Short

- Mr. William Kreider

- Mr. Roger Maas

- Mr. Michael Sciarini

Cedar Lane Farms Incorporated:

- Mr. Thomas Machamer

- Mr. Bruce Machamer

Will-Burt Company:

- Mr. Dennis Donahue

- Mr. Walter Stashkiw

\section{AUTHORS}

The following personnel contributed in the preparation of this report:

Energy and Environmental Research Corporation

Robert A. Ashworth

Duane A. Plessinger

Todd M. Sommer

Ohio Agricultural Research and Development Center (OARDC):

Dr. Harold M. Keener

Will-Burt Company

Rodney L. Webner 


\title{
POINTS OF CONTACT
}

For more information regarding the Small Scale Atmospheric Fluidized Bed Combustor technologies, please contact:

\author{
Mr. Rodney Webner \\ Senior Product Manager \\ or \\ Mr. Larry Pierce \\ Manager, Heating Product Sales \\ Will-Burt Company \\ 169 S. Main St. \\ Orrville, $\mathrm{OH} 44667$ \\ Phone (216) 682-7015 \\ Fax (216) 684-1190 \\ Mr. Todd M. Sommer \\ Vice President \\ or \\ Mr. Robert A. Ashworth \\ Manager - Advanced Systems \\ Energy and Environmental Research Corporation \\ 1345 N. Main St. \\ P.O. Box 153 \\ Orrville, $\mathrm{OH} 44667$ \\ Phone (216) 682-4007 \\ Fax (216) 684-2110
}




\section{TABLE OF CONTENTS}

\section{$\underline{\text { Page }}$}

EXECUTIVE SUMMARY

1.0 INTRODUCTION 1

2.0 AFBC DEVELOPMENT PROGRAM 2

3.0 PROOF-OF-CONCEPT DEMONSTRATION 3

3.1 Demonstration Program 3

3.2 AFBC Design 8

3.3 AFBC Process Description 11

3.4 Operations Assessment 14

3.5 Data Analyses 24

4.0 COMMERCIAL UNIT DESIGN

4.1 Process Description 35

4.2 Mass and Energy Balances $\quad 39$

4.3 Piping and Instrumentation 39

4.4 Equipment List 45

4.5 Equipment Layout and Elevations $\quad 48$

4.6 Cost Estimate 48

4.7 Economics 50

$\begin{array}{lll}5.0 & \text { MARKETS } & 60\end{array}$

$\begin{array}{lll}6.0 & \text { BUDGET SUMMATION } & 62\end{array}$

APPENDIX

Technical Papers:

Small Scale AFBC Hot Air Gas Turbine Power Cycle

Environmental Performance of Air Staged Combustor with Flue Gas Recirculation to Burn Coal/Biomass

$A F B C$ - Operation of Small Scale Demonstration for Greenhouse Heating

$A F B C-H A G T$, an Efficient Small Scale Power Plant

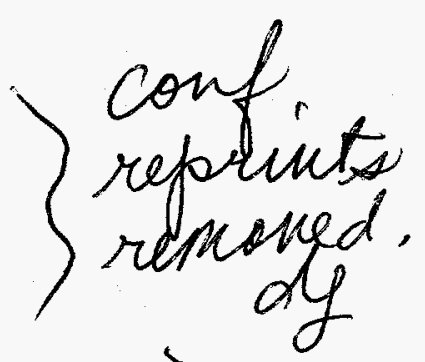




\section{LIST OF ABBREVIATIONS}

AFBC

ASME

ASAE

CAAA

CEMS

CFR

CLF

DOE

EER

FGR

HAGT

HHV

LOI

NSPS

OARDC

OCDO

U.S. EPA

WB
Atmospheric Fluidized Bed Combustor

American Society of Mechanical Engineers

American Society of Agricultural Engineers

Clean Air Act Amendments

Continuous Emissions Monitoring System

Code of Federal Regulations

Cedar Lane Farms, Inc.

United States Department of Energy

Energy and Environmental Research Corporation

Flue Gas Recirculation

Hot Air Gas Turbine

Higher Heating Value

Loss on Ignition

New Source Performance Standards

Ohio Agricultural Research and Development Center

Ohio Coal Development Office

United States Environmental Protection Agency

Will-Burt Company 


\section{LIST OF UNITS}

acf
acfm
$\mathrm{Btu} / \mathrm{kWhr}$
$\mathrm{Btu} / \mathrm{hr}$
$\mathrm{Btu} / \mathrm{lb}$
$\mathrm{Btu} / \mathrm{scf}$
$\mathrm{dscfm}$
${ }^{\circ} \mathrm{F}$
$\mathrm{ft}$
$\mathrm{ft}^{2}$
$\mathrm{ft}^{2} / 1000 \mathrm{acfm}$
$\mathrm{ft}^{3}$
$\mathrm{ft}^{\mathrm{s}}$
$\mathrm{gpm}$
$\mathrm{gr} / \mathrm{dscf}$
$\mathrm{HP}$
$\mathrm{in}$
$\mathrm{lb} / \mathrm{ft}^{3}$
$\mathrm{lb} / \mathrm{hr}$
$\mathrm{lb} / \mathrm{min}$
$\mathrm{lb} / 10^{6} \mathrm{Btu}$
$\mathrm{MW} \mathrm{e}$
$\mathrm{psig}$
$\mathrm{ppmv}$
$\mathrm{ppmw}$
$\mathrm{scfh}$
$\mathrm{scfm}$
$\mathrm{sfgv}$
$\%$

Actual Cubic Foot

Actual Cubic Foot per Minute

British Thermal Unit per Kilowatt-hour

British Thermal Unit per Hour

British Thermal Unit per pound

British Thermal Unit per Standard Cubic Foot

Dry Standard Cubic Foot per Minute

Degree Fahrenheit

Foot

Square Foot

Square Foot per Thousand Actual Cubic Feet per Minute

Cubic Foot

Foot per Second

Gallon per Minute

Grains per Dry Standard Cubic Foot

Horsepower

Inch

Pound per Cubic Foot

Pound per Hour

Pound per Minute

Pound per Million British Thermal Units

Megawatt Electric

Pound per Square Inch (Gauge)

Parts per Million Volume

Parts per Million Weight

Standard Cubic Foot per Hour

Standard Cubic Foot per Minute

Superficial Gas Velocity

Percent 


\section{GLOSSARY OF TERMS}

Chemical Symbols:

$\begin{array}{ll}\mathrm{Al}_{2} \mathrm{O}_{3} & \text { Aluminum Oxide (Alumina) } \\ \mathrm{BaO} & \text { Barium Oxide } \\ \mathrm{C} & \text { Carbon } \\ \mathrm{Ca} & \text { Calcium } \\ \mathrm{CaCO} & \text { Calcium Carbonate } \\ \mathrm{CaO} & \text { Calcium Oxide } \\ \mathrm{Ca} / \mathrm{S} & \text { Calcium (Sorbent) to Sulfur (Coal) Molar Ratio } \\ \mathrm{CaSO} & \text { Calcium Sulfite } \\ \mathrm{CaSO} & \text { Calcium Sulfate } \\ \mathrm{Cl} & \text { Chlorine } \\ \mathrm{CO} & \text { Carbon Monoxide } \\ \mathrm{CO} & \text { Carbon Dioxide } \\ \mathrm{Fe}_{2} \mathrm{O}_{3} & \text { Ferric Oxide } \\ \mathrm{H}_{2} & \text { Hydrogen (Diatomic) } \\ \mathrm{HCl}_{\mathrm{H}_{2} \mathrm{O}} & \text { Hydrogen Chloride } \\ \mathrm{K}_{2} \mathrm{O} & \text { Water } \\ \mathrm{MgCO}_{3} & \text { Potassium Oxide } \\ \mathrm{MgO} & \text { Magnesium Carbonate } \\ \mathrm{MnO}_{2} & \text { Magnesium Oxide } \\ \mathrm{N}_{2} & \text { Manganese Oxide } \\ \mathrm{Na}_{2} \mathrm{O} & \text { Nitrogen (Diatomic) } \\ \mathrm{NO}_{x} & \text { Sodium Oxide } \\ \mathrm{NO}_{\mathrm{NO}_{2}} & \text { Nitrogen Oxides } \\ \mathrm{N}_{2} \mathrm{O} & \text { Nitric Oxide (Colorless Gas) } \\ \mathrm{P}_{2} \mathrm{O}_{5} & \text { Nitrogen Dioxide (Reddish Brown Gas) } \\ \mathrm{O}_{2} & \text { Nitrous Oxide (Colorless Gas) } \\ \mathrm{S}_{\mathrm{SiO}_{2}} & \text { Phosphorous Pentoxide } \\ \mathrm{SO}_{2} & \text { Oxygen (Diatomic) } \\ \mathrm{SO}_{3} & \text { Sulfur } \\ \mathrm{SrO}_{\mathrm{TiO}} & \text { Silicon Dioxide (Silica) } \\ \mathrm{TiO}_{2} & \text { Sulfur Dioxide } \\ & \text { Sulfur Trioxide } \\ \text { Strontium Oxide } \\ \text { Titanium Oxide } \\ \end{array}$




\section{EXECUTIVE SUMMARY}

The objective of this project was to demonstrate and promote the commercialization of coal-fired atmospheric fluidized bed combustion (AFBC) systems, with limestone addition for $\mathrm{SO}_{2}$ emissions control and a baghouse for particulate emissions control. This AFBC system was targeted for small scale industrial-commercial-institutional space and process heat applications. A cost effective and environmentally acceptable AFBC technology in this size range would displace a considerable amount of gas/oil with coal while resulting in significant total cost savings to the owner/operators.

A project team was assembled that provided state-of-the-art small AFBC technology and experience in engineering, manufacturing and marketing of small coal-fired equipment (stokers) for residential, commercial, and small industrial use. The original members of this team were the Ohio Agricultural Research and Development Center of Ohio State University (OARDC), the Will-Burt Company and the Energy and Environmental Research Corporation (EER). The overall program was completed through three phases of development: Feasibility, Subsystem Development and Integration, and Proof-of-Concept. In the Feasibility Phase the technical/ economical feasibility of a $1 \times 10^{6} \mathrm{Btu} / \mathrm{hr}$ coal-fired AFBC air heater was evaluated. In the Subsystem Development and Integration Phase a small scale $\left(1.5 \times 10^{6} \mathrm{Btu} / \mathrm{hr}\right)$ atmospheric fluidized bed combustion system was developed and tested. In this phase, the goal of reducing $\mathrm{SO}_{2}$ emissions to $1.2 \mathrm{lb} / 10^{6} \mathrm{Btu}$, from high sulfur Ohio coal, was achieved by adding limestone with a $\mathrm{Ca} / \mathrm{S}_{\text {coal }}$ ratio of $\sim 3.0$. This testing was accomplished at OARDC facilities in Wooster, $\mathrm{OH}$.

In the Proof-of-Concept Phase, a $2.2 \times 10^{6} \mathrm{Btu} / \mathrm{hr}$ unit was installed and successfully operated at Cedar Lane Farms (CLF), a commercial nursery in Ohio. The U.S. DOE sponsored the development effort through all four levels. The Ohio Coal Development Office (OCDO) was the major funding sponsor for the Proof-of Concept Phase. For this project, the heat from the fluidized bed was used to heat hot water which was recirculated through greenhouses for cool weather heating. The system was designed to be fully automated with minimal operator attention required. The AFBC system installed at CLF was an improved design that incorporated flyash/sorbent reinjection and an underbed feed system to improve limestone utilization. With these additions it was possible to lower the $\mathrm{Ca} / \mathrm{S}$ ratio from $\sim 3.0$ to 2.0 , and still maintain an $\mathrm{SO}_{2}$ emissions level of $1.2 \mathrm{lb} / 10^{6}$ Btu when burning the same high sulfur Ohio coal tested at OARDC. 
As part of the Proof-of-Concept Phase, the Will-Burt Company contracted the Energy and Environmental Research Corporation (EER) to complete a design and cost estimate for a commercial scale $10 \times 10^{6} \mathrm{Btu} / \mathrm{hr}$ Atmospheric Fluidized Bed Combustion System (AFBC) to generate hot water for small scale industrial-commercial-institutional heating applications. The design and cost estimate for the $10 \times 10^{6} \mathrm{Btu} / \mathrm{hr} \mathrm{AFBC}$ system was part of the agreement by the Will-Burt Company for partial cost sharing of the Ohio Coal Development Office (OCDO) grant extension for the Cedar Lane Farms (CLF) AFBC Project. The CLF AFBC (nominally $2.2 \times 10^{6}$ $\mathrm{Btu} / \mathrm{hr}$ ) was the prototype upon which the design basis for the larger unit.

The operational experience on the CLF AFBC was used to develop an improved design for a $10 \times 10^{6} \mathrm{Btu} / \mathrm{hr}$ commercial size AFBC. A detail combustor design was completed for Will-Burt so they could develop definitive fabrication costs for the combustor. A new coal distributor was also designed for the AFBC that will provide uniform distribution of coal and limestone throughout the fluidized bed and reduce the possibility of sand backflow into the feed transport line. A new low pressure drop startup heater for the combustor was also selected and incorporated into the new design. This new heater will reduce capital and electrical power costs for the AFBC.

A preliminary design was also completed for the balance of plant equipment, and quotations were received on all major equipment items. Where Will-Burt equipment could be applied, such equipment was included; e.g. screw conveyors, hoppers/feeders, and eductors. The hot water heater was changed from larger diameter horizontal tubes to smaller diameter slanted horizontal tubes to facilitate a better flyash-sorbent recirculation system and to eliminate the need for a mechanical sootblower. Elimination of the mechanical sootblower reduces both capital and operating cost. Also, the new hot water heater design has only one tube pass rather than three. This feature reduces the capital cost for the larger unit.

An air blower was selected to transport the coal/limestone into the AFBC. The use of a separate coal/limestone air blower was found during the CLF operation to decrease the tendency of the coal feed pipe to plug. By using air from a separate air blower, rather than flue gas (the original technique used at CLF) from the flue gas recycle blower, electrical power consumption is reduced. Less gas is required at the high pressure used for coal/limestone transport. With this new design also, a separate air blower and flue gas recycle blower is used rather than the combined approach used in the CLF system. This modification will provide for better control of system oxygen that will insure maximum thermal efficiency for the unit. 
Installed system costs were developed for both the AFBC system and an identical size natural gas fired system. The total plant investment for the AFBC system is estimated at $\$ 558,000$. Including fixed charges @ 10\% to payoff capital, the cost to operate the AFBC system, with coal being purchased at $\$ 30 /$ ton $(\sim 1.18 /$ million Btu) is estimated at $\$ 232,180 /$ year or a cost of hot water of $\$ 4.44 /$ million Btu (basis 250 days/year operation). Based on 250 and 300 days of operation, at full load, the cost of $\mathrm{SO}_{2}$ removal, reducing emissions from $5.185 \mathrm{lb} / 10^{6} \mathrm{Btu}$ down to $1.2 \mathrm{lb} / 10^{6} \mathrm{Btu}$ is $\$ 1780$ and $\$ 1650 /$ ton, respectively.

The total plant investment for the natural gas fired system was estimated at $\$ 82,443$. Using the same fixed charge rate as that used for the AFBC system to payoff capital, and a gas purchase price of $\$ 4.50 /$ million Btu (the price CLF paid in 1996) and the same on-stream service factor, the cost of hot water produced is projected at $\$ 6.09 /$ million Btu. Compared to the AFBC system, this results in an increase of $\$ 1.65 /$ million Btu for hot water from a gas fired unit. The price differential of natural gas to coal is the critical cost component in determining the economic advantage/disadvantage of an AFBC system relative to a natural gas fired system. With reasonable capacity factors for a specific heating system, an AFBC of this size can provide an economic advantage to a natural gas fired system, when the purchased price of natural gas is greater than about $\$ 3.20 /$ million Btu. The average cost of natural gas to the industrial and commercial market sectors in February of 1997 was $\$ 4.21$ and $\$ 5.98 / 10^{6}$ Btu, respectively. Based on current natural gas prices, the AFBC unit, at the $10 \times 10^{6} \mathrm{Btu} / \mathrm{hr}$ size, is the best economical choice for new heating systems.

The State Energy Data Report of 1994, showed an annual energy consumption of $547 \times 10^{12}$ Btu by the industrial/commercial market sector in Ohio. Based on a U.S. EPA study, commercial /industrial boilers in the size range of 7.3 to 29.3 million $\mathrm{Btu} / \mathrm{hr}$, firing mostly natural gas and fuel oil, and make up about $25 \%$ of the total energy consumed by the industrial/commercial market sector. Applying this percentage of energy consumption to the State of Ohio, in 1994 it was estimated that boilers in the above size range consumed about $137 \times 10^{12} \mathrm{Btu} /$ year.

The AFBC developed under this program has applicability to boilers in this size range. Assuming that coal fired in the AFBC units could increase coal consumption in this sector by $10 \%$ of the 1994 market share, by the year 2010 Ohio coal consumption would increase about 550,000 tons/year. To obtain this increase in market share would require the installation of some 225 - 10 million Btu/hr AFBC units (@ 70\% capacity factors). The additional coal used 
by these AFBC units would provide a $7.5 \%$ increase in coal consumption compared to that reported for the Ohio commercial/industrial market sector in 1994.

The AFBC development has been very successful and widespread implementation of this AFBC system, could well start to reverse the trend of decreasing coal use by the commercial, industrial, and institutional market sectors. With the widespread use of this technology, other benefits will arise in the form of increased business revenues from the sale of indigenous limestone, and the possible sale of the flyash/sorbent byproduct as a soil cement or soil conditioner. The AFBC will also provide a reduction in fuel costs for the users of the technology that will help make their products more cost competitive. The commercialization of the AFBC will result in a new technology that will be fabricated in Ohio and marketed throughout the United States and abroad.

The overall cost of the Cedar Lane Farms prototype AFBC program was $\$ 841,714$. The Ohio Coal Development Office funded $\$ 410,798$ or $48.80 \%$ of the program cost. The development team of EER, the Will-Burt Company, the U.S. DOE, OARDC, and CLF funded $\$ 430,916$ or $51.2 \%$ of the program cost. This compares to the cost proposal included as part of the grant agreement with OCDO for a total project cost of $\$ 825,322$ wherein OCDO agreed to fund $\$ 410,798(49.77 \%)$ with the development team funding $\$ 414,524(50.23 \%)$. 


\subsection{INTRODUCTION}

Currently, oil and gas are the fuels of choice for the space and process heat requirements of commercial and small industrial applications. This is because of the convenience and cleanliness offered by these fuels compared to coal. However, there are certain socioeconomic pressures in coal producing states, especially Ohio, to provide technologies which will enhance the acceptability of coal for these applications.

Commercial/small industrial boilers, i.e., those in the range of 7.3 to 29.3 million Btu/hr use mostly natural gas and oil and make up some $25 \%$ of the total gas and oil consumption. In the State of Ohio assuming a $50 \%$ capacity factor, these boilers in 1994 consumed about $68.4 \times 10^{12}$ Btu/year. It is estimated that if $25 \%$ of the oil and gas-fired boilers/heaters in this size range were converted to coal, then Ohio coal consumption would be increased by some 684,000 tons/year, or approximately $10 \%$ of the coal used in the commercial/industrial market sector in Ohio in 1994.

Atmospheric fluidized bed combustion offers several potential advantages over conventional coal combustion systems for small scale market applications:

Minimal Fuel Processing. The combustion process is not overly sensitive to the physical characteristics of the coal feed. This characteristic allows for lower purchased coal prices compared to conventional stoker systems that require a certain coal size consist.

Low Temperature Combustion. Fluidized beds operate at low temperatures. This avoids problems such as clinker formation and slagging which are major areas of concern with certain other coal fired systems.

$\mathrm{SO}_{2}$ Emission Control. Limestone sorbent in the fluid bed reacts with $\mathrm{SO}_{2}$ liberated during the combustion process to control $\mathrm{SO}_{2}$ emissions. Emissions can be reduced in excess of 80 percent.

Potential small scale coal-fired, AFBC users include institutions (schools, hospitals, prisons, government), light industry (agriculture, food processing), commercial buildings (shopping centers), and large residential buildings (apartment complexes). 
Fluidized bed combustion systems have been developed for several applications. However, at the start of this development program there was no commercial equipment available in the size range for small scale market sectors. The overall goals of this program were as follows:

1. To demonstrate that an atmospheric fluidized bed combustor (AFBC) could satisfy the market/environmental requirements for small commercial and industrial heating systems.

2. To provide the necessary background of operating experience to ensure the market acceptability of a small scale AFBC.

3. To actively promote the commercialization of the AFBC.

The first two goals have been met, and the Will-Burt Company, with support from EER is actively marketing the developed product.

\subsection{AFBC DEVELOPMENT PROGRAM}

The overall objective of this program was to develop a commercially viable small scale AFBC system. This provided the incentive for the assembled team members' participation in the program. The Will-Burt Company is a manufacturer of small coal fired under-feed stoker combustion equipment. While the market for this equipment had persisted for decades, the growth potential was seen to be severely limited. In most applications, under-feed stokers could not compete with gas/oil fired equipment in terms of convenience, emissions and total cost. Will-Burt had an interest in exploring new combustion technology to meet the future needs of its clients. They conducted an intensive review of alternate small scale coal-fired combustion technology and identified AFBC technology as a prime candidate for development. This review spawned the interest in the AFBC development that has recently been completed.

A team including the Energy and Environmental Research Corporation (EER), the Ohio Agricultural Research and Development Center (OARDC) - The Ohio State University, and the Will-Burt Company were assembled. Commercialization agreements were set in place among the technology developers, OARDC, EER and Will-Burt for the development and eventual marketing of the technology. The goals of the development program were met and the Will-Burt Company, the marketing arm of the team, is currently testing the market potential for the AFBC 
technology to small scale industrial-commercial-institutional market sectors in the U.S. and abroad. However, before commercialization efforts can be fully supported, a commercial size AFBC $\left(10 \times 10^{6} \mathrm{Btu} / \mathrm{hr}\right.$ size $)$ must be demonstrated.

\subsection{PROOF-OF-CONCEPT DEMONSTRATION}

The objective of the proof-of-concept demonstration project was to prove the economical and technical viability of small scale atmospheric fluidized bed combustion (AFBC) systems for use in the generation of hot water for greenhouse heating. A team including the Energy and Environmental Research Corporation (EER), the Ohio Agricultural Research and Development Center (OARDC) - The Ohio State University, the Will-Burt Company, Cedar Lane Farms, and the U.S. DOE (METC) submitted a proposal to the OCDO for co-funding of the AFBC development. The proposal was accepted and an award made to the team on April 1, 1994.

The host site for this demonstration was Cedar Lane Farms, Inc., a nursery near Wooster, Ohio. Cedar Lane Farms grows/produces roses, perennials, flowering hanging baskets, potted flowering plants, blooming annual and vegetable flats, pansy and primrose baskets and poinsettias. The greenhouse area under glass and heated by Cedar Lane Farms totals some $200,000 \mathrm{ft}^{2}$, the AFBC provides heat to a portion of this greenhouse area. The AFBC ties into an existing hot water heating system that includes one coal-fired stoker and two natural gas-fired hot water heaters.

\subsection{Demonstration Program}

The proof-of-concept phase (commercial prototype application) was completed in three major phases of work.

- $\quad$ Phase 1 - Engineering/Purchasing

- $\quad$ Phase 2 - Construction and Startup

- $\quad$ Phase 3 - Long Term Testing 


\subsubsection{Phase 1 - Engineering/Purchasing}

The purpose of this phase of work was to complete the engineering design and purchase of equipment that was required in addition to the existing pilot plant equipment, for the commercial demonstration at Cedar Lane Farms. This work was the responsibility of EER; all of the engineering and purchasing activities were completed at EER's engineering offices in Orrville, Ohio. Design activities included the development of mass and energy balances, process flow diagrams, piping and instrument diagrams, process control logic, specification of process equipment, piping specifications, and electrical equipment, equipment layout drawings and structural and civil work. Following specification of equipment and process controls, items required for the construction phase of the project were purchased. The major tasks within Phase 1 were as follows:

\section{Task 1 - Process Engineering}

This task consisted of the development of mass and energy balances, process flow diagrams, preliminary piping and instrument diagrams, sizing of process equipment, and conceptual control logic.

\section{Task 2 - Permits}

EER completed permit applications for the installation and operation of the AFBC system and submitted them to the Ohio EPA. From a pollution perspective, small AFBC units with heat inputs greater than 10 million Btu/hr must comply with the EPA 40 CFR Part 60, "Standards of Performance for New Stationary Sources: Small Industrial-Commercial-Institutional Steam Generating Units; Final Rule - (Federal Register, September 12, 1990)." Although the combustors under development have capacities of 10 million $\mathrm{Btu} / \mathrm{hr}$ and less, the limitations under this regulation were used to set the pollutant limits for the combustor. The affected facility to which these standards apply is to each steam generating unit for which construction, modification, or reconstruction is commenced after June 9,1989 and that has a maximum design heat input of 100 million Btu/hr or less, but greater than or equal to 10 million Btu/hr.

\section{Standards for Sulfur Dioxide}

For coal fired steam generating units with greater than 10 million Btu/hr heat input capacities, but less than 75 million Btu/hr heat input capacities, the standards limit $\mathrm{SO}_{2}$ emissions to $1.2 \mathrm{lb} /$ million Btu coal fired. 


\section{Standards for Particulate Matter}

For coal fired steam generating units with heat input capacities greater than 30 million Btu/hr the standards limit particulate matter to $0.05 \mathrm{lb} /$ million Btu of coal fired and limit the opacity to $20 \%$.

\section{Standards for Nitrogen Oxides}

For coal fired steam generating units with heat input capacities of 100 million $\mathrm{Btu} / \mathrm{hr}$ and less, there are no standards promulgated for $\mathrm{NO}_{\mathrm{x}}$.

\section{Water and Solid Waste}

No significant water pollution impacts are projected, and the projected impacts on solid waste generation are small. In addition, the wastes produced by particulate matter control processes are nonhazardous and can be disposed of using traditional treatment and disposal techniques.

\section{Task 3 - Detail Design Engineering}

This task included all of the detail engineering activities required for purchasing and installation of equipment. These activities included detailed specification and selection of process, control, piping and electrical equipment; the development of finalized piping, instrument and electrical diagrams; and structural and civil engineering.

\section{Task 4 - Purchasing}

This task included the purchase of all new equipment required for the installation of the AFBC system at Cedar Lane Farms. Existing pilot plant equipment currently located at OARDC was moved to the Cedar Lane Farms facility. EER used its standard procurement procedures for purchase of equipment items, which included multiple steps for $\mathrm{QA} / \mathrm{QC}$ on all equipment purchased. This included purchase order preparation and approval and receipt/inspection of equipment. On all new equipment items purchased, at least three quotations for each equipment item were obtained from reputable vendors. Equipment was selected based on the following criteria; price, features, and services provided by vendor.

The completion of this phase of work resulted in an engineering design for the proof-of-concept facility using the AFBC with a flue gas recirculation (FGR) system that provides for high thermal efficiency; reduced sulfur dioxide emissions from the firing of high sulfur coal; reduced 
$\mathrm{NO}_{\mathrm{x}}$ emissions, and a clean stack (very minimal particulate emissions as a result of the use of a bag house). This design, although applied to a hot water heating system would also be viable, with minimal design modifications for steam generation. The control system logic developed is applicable for hot water, steam and electric power generation.

\subsubsection{Phase 2 - Construction and Startup}

The construction activities included civil work at Cedar Lane Farms, installation of process, instrumentation and electrical equipment, process piping, and hookup of other utilities required for operation of the unit. It also included building modifications for equipment installation. Following construction, all of the process equipment, instruments and electrical wiring connections were checked out prior to start-up. This phase was the prime responsibility of the EER's engineering office personnel located at Orrville, Ohio, with assistance provided from OARDC personnel, located in Wooster, Ohio. EER subcontracted specific construction tasks to local mechanical contractors. During the start-up phase, EER trained the Cedar Lane Farm utility operators to operate the AFBC system. The major tasks within Phase 2 were as follows:

\section{Task 1 - Construction}

This task consisted of the removal of equipment presently at OARDC and the relocation and reinstallation of this equipment at Cedar Lane Farms. It also included the installation of new process, instrumentation and electrical equipment to provide a complete installation. This task also included civil and structural work.

\section{Task 2 - Checkout of Equipment}

Prior to start-up EER and the Cedar Lane Farms personnel checked out the equipment. EER contacted the Ohio EPA to obtain approval to operate. Although the formal permits had not been obtained, the EPA gave EER verbal approval to startup the unit.

\section{Task 3 - Startup and Operator Training}

Following checkout of equipment, EER and Cedar Lane Farms personnel started up the unit and tested it at various conditions to assess the overall operability of the unit. During this time frame, EER, trained the Cedar Lane Farm operators in the safe operation of the atmospheric fluidized bed combustion/hot water heating system. 


\subsubsection{Phase 3 - Long Term Testing}

Following successful startup, and short duration parametric testing, the long term testing program was initiated. The long term testing of the unit AFBC system was completed under the normal operating load requirements of Cedar Lane Farms. The Cedar Lane Farms heating load requirements determined the coal feed rate to the unit. For the testing completed, data were recorded on a computer data logger. This data provided the necessary information to complete mass and energy balances around the unit and to determine the rate of $\mathrm{SO}_{2}$ and $\mathrm{NO}_{\mathrm{x}}$ emissions. This phase of work was the prime responsibility of Cedar Lane Farms Corporation, located in Wooster, Ohio. EER and Will-Burt personnel located at Orrville, Ohio, with assistance from OARDC personnel, located in Wooster, Ohio assisted in operations. EER completed the testing and data reduction. The major tasks completed within Phase 3 were as follows:

\section{Task 1 - Operations Setup}

This task consisted of running various tests to determine the best conditions for long term operation. During this task, the desired control point of oxygen in the flue gas was determined, as well as the best temperature for sulfur control and the $\mathrm{Ca} / \mathrm{S}$ ratio required to meet the $1.2 \mathrm{lb}$ $\mathrm{SO}_{2} /$ million Btu of coal fired.

\section{Task 2 - Normal Operations Mode}

This task was the normal operations period when the AFBC was run in a manner to meet the cyclic heating load of the Cedar Lane Farms green houses. The unit has been operated for two heating seasons.

\section{Task 3 - Final Report}

This final report covers all of the aspects of the commercial demonstration project; design, construction, operations, data analyses and an updated economic assessment of the technology based on the information gained over the long term testing.

The successful conclusion of this phase of work has demonstrated a commercially viable clean coal technology that can be scaled up to a commercial size for use by the small scale industrial, institutional and commercial users. 


\subsection{AFBC Design}

The AFBC system is designed to fire $-1 / 2 "$ coal. Limestone is fed with the coal to act as a sorbent for reduction of sulfur dioxide emissions. Sand, which is an inert material, is used as the fluid bed media. A simple auger/pneumatic feed system is used to feed coal and limestone into the combustor. The AFBC proper is designed with simplicity as the prime input, recognizing that small scale operators do not have the resources to maintain a large staff, with the diverse talents necessary, to operate and maintain a complex system. The combustor is a cylindrical, refractory lined vessel with no heat transfer surfaces or pressure parts. This type of AFBC, although lower in overall thermal efficiency is more amendable for retro-fitting existing small scale boilers than AFBC units with in-bed tubes. Further, because there are no in-bed tubes to remove heat, the system may be banked for some 4 to 6 hours without the need for auxiliary fuel. This AFBC is therefore better suited for cyclical service applications such as exist in greenhouse heating applications. Also, the only maintenance that has to be done on this type of FBC is relegated to refractory and possible grid plate repair.

A unique design feature of this fluidized bed combustor, is the use of flue gas recycle plus fresh air for feed throughput control. The flue gas recycle technique restores some of the thermal efficiency loss incurred by not having tubes in the bed. It improves the overall thermal efficiency of this AFBC system by some $3.5 \%$ to $5 \%$. Further, by controlling the amount of fresh air being drawn into the system, the oxygen content at the exit of the fluid bed is controlled to maximize thermal efficiency and still provide for good combustion conditions within the fluid bed. When firing Ohio coal, by controlling the oxygen content at a level to yield approximately $200 \mathrm{ppmv}$ of carbon monoxide in the flue gas, $\mathrm{NO}_{\mathrm{x}}$ emissions can be significantly reduced.

During the pilot plant test runs and subsequent data analyses, certain questions were raised which needed to be resolved by long term testing in the commercial unit. First of all, in the pilot plant work, an air eductor was used to inject coal and limestone into the combustor through a sidewall near the top of the fluid bed. With the use of this injection point it was observed through the combustor viewport that a significant amount of coal was burning in suspension above the fluid bed. It was also expected that limestone was being entrained fairly rapidly from the bed. By not having the coal combustion take place in the bed which has rapid heat transfer, it was felt that more $\mathrm{NO}_{\mathrm{x}}$ production could be occurring with suspension burning due to higher localized 
temperatures. Further, by rapidly entraining a portion of the feed limestone out of the combustor, it was felt that the calcium utilization for sulfur capture was less than it would be if the limestone sorbent were to stay in the bed longer.

A new coal feed system was designed to introduce coal and limestone, via an auger, into the center and bottom of the bed. This design was tested on the pilot unit and then used on the commercial unit. Further, the entrainment of unreacted coal and limestone from the bed should both be reduced with this new design. It was expected that this feature would reduce $\mathrm{NO}_{x}$ emissions somewhat and also improve sorbent utilization and in fact it did.

The second design change was to use sorbent reinjection to improve calcium utilization. A mechanical collector was installed on the flue gas line at the exit of the AFBC, prior to the waste heat recovery hot water heater, for the removal of large particles of sorbent and uncombusted char. The bottom conical section of the collector feeds into an eductor where recycled flue gas is used as the motive force to educt sorbent and char back into the fluid bed.

In the pilot plant operation the coal feed rate was set and the flue gas recycle rate was automatically adjusted to maintain bed temperature. For the commercial demonstration, the coal feed rate was controlled automatically to maintain the desired bed temperature, and recycle flue gas was automatically controlled to respond to the thermal load. Fresh air feed into the system was controlled to maximize efficiency and reduce $\mathrm{NO}_{x}$ emissions.

The hot water heater used in the commercial demonstration was slightly oversized to determine if greater coal heat inputs can be obtained. The commercial unit, using the same AFBC was designed for a maximum feed rate of $2.2 \times 10^{6} \mathrm{Btu} / \mathrm{hr}$ of coal as opposed to the $1.5 \times 10^{6} \mathrm{Btu} / \mathrm{hr}$ of coal design for the pilot unit. Larger size sand was used in the fluid bed so that superficial gas velocities could be increased. The higher the coal throughput per unit volume of the AFBC the lower is the fixed charge component of the operating cost to pay back the capital cost. 
The Cedar Lane Farms demonstration unit was designed to use much of the existing equipment at the OARDC facility. The new equipment that was purchased for the demonstration unit is delineated below:

- Coal Screen - Required for screening of ROM coal, larger size coal used in a coal stoker and $-1 / 2$ " size coal fed to the AFBC. The screen was installed but kept plugging up so it was removed and replaced with the crusher discussed below.

- Coal Crusher - The coal screen did not work, so a crusher was purchased to replace the screen. A partial rebate was obtained from the screen supplier.

- $\quad$ Coal and Limestone Conveyors - Required for feed supply to storage bins

- Coal and Limestone Bins - Required for feed supply to combustor and for storage

- $\quad$ Fluid Bed Combustor Revamp - Upper refractory upgrade is needed for long term testing

- Mechanical Collector - Required to collect sorbent for reinjection

- Hot Water Heater - Replacement for existing unit - designed to better handle solids

- $\quad$ Bag House - Replacement for bag house that was lent by OARDC for pilot plant testing

- Water Pump - Required for hot water recirculation

- Data Collection Instruments - Required for monitoring of long term pilot testing

The balance of equipment and instruments was provided by moving the existing equipment and instruments from the OARDC facility to Cedar Lane Farms. The AFBC operation at Cedar Lane Farms was monitored through use of a 16-point data logger. The data taken, included the following:

1) $\mathrm{AFBC}$ bed temperature

2) AFBC flue gas exit temperature

3) Temperature of the flue gas exiting the hot water heater

4) Stack temperature

5) Flue gas recycle temperature

6) Hot water heater inlet water temperature

7) Hot water heater outlet water temperature

8) Hot water recirculation rate, gpm

9) $\mathrm{AFBC}$ pressure, in. of water (negative)

10) Flue gas recycle rate, scfh

11) Stack gas oxygen content, \%

12) Stack gas carbon monoxide content, ppmvd

13) Stack gas $\mathrm{NO}_{\mathrm{x}}$ content, ppmvd

14) Stack gas $\mathrm{SO}_{2}$ content, ppmvd 


\subsection{AFBC Process Description}

The combustion system installed at Cedar Lane Farms uses an AFBC that operates at 1500 to $1600^{\circ} \mathrm{F}$ and near atmospheric operating pressure (see Figures 3-1 and 3-2). Stoker coal $\left(\sim 2^{\prime \prime} \times 1 / 2 "\right.$ size) is unloaded using an existing belt conveyor that transports the coal to an existing coal storage bin. This bin provides the coal feed to both the coal-fired stoker and the AFBC. From the coal storage bin, the coal is augured to a jaw crusher that crushes the coal to a minus $1 / 2$ " size and the coal from the crusher feeds into a coal auger feed bin. The feed bin coal is augured into a standpipe that feeds a rotary lock feeder.

In parallel to the coal feed, limestone from a separate feed bin is also augured into the standpipe. Coal and limestone from the rotary feeder fall into a pneumatic transport line. A separate air blower (installed during the test phase) supplies the air that is used as the transport media. Coal and limestone are blown through a transport line that enters the combustor wind box and then passes up through the center of the air distribution grid plate into the bottom of the fluid bed. Graded sand is used as the inert fluid bed media.

Coal combustion and sulfur dioxide capture take place in the fluid bed. The coal rate is set to provide the energy release to maintain the fluid bed temperature and the limestone:coal ratio is set to yield the $\mathrm{SO}_{2}$ capture desired. The hot flue gas from the combustor flows through a mechanical collector where large particles of coke and sorbent are removed and pneumatically recycled back into the fluid bed. Recycled flue gas is also used here as the transport media. The purpose of this reinjection technique is to yield better calcium (limestone) utilization for $\mathrm{SO}_{2}$ capture.

Hot flue gas from the collector then enters a waste heat recovery hot water heater. The cooled flue gas from the hot water heater exits at a temperature of approximately $300{ }^{\circ} \mathrm{F}$ and enters a cartridge dust collector for particulate removal. An induced draft fan on the exit of the dust collector provides the motive force to draw the flue gas from the combustor, maintaining a slight negative pressure at the combustor flue gas outlet. The induced draft fan discharges into an atmospheric stack.

Flue gas from the dust collector is also recycled back to the windbox of the combustor for temperature control. A controlled rate of fresh air is drawn into the suction of the recycle 


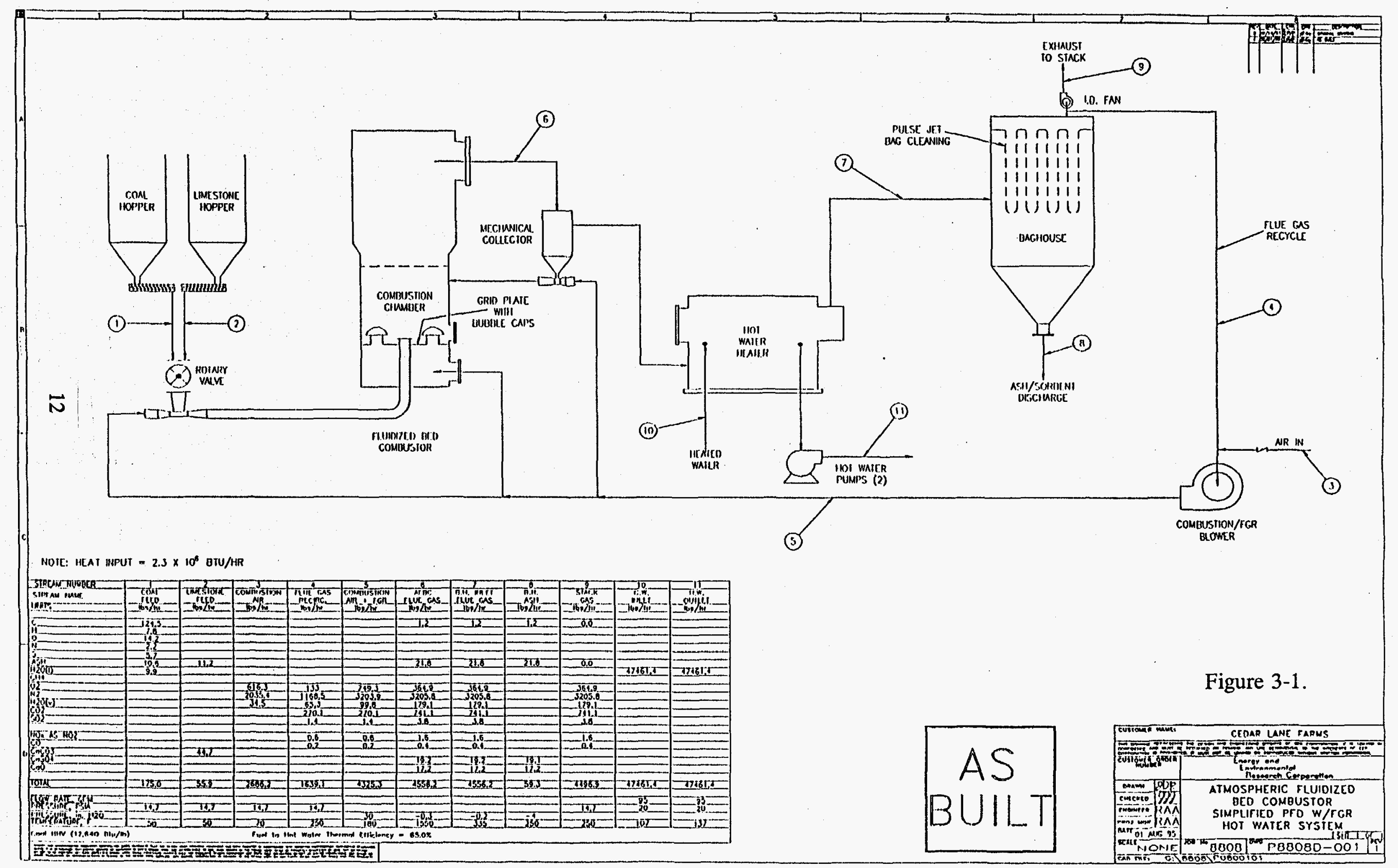




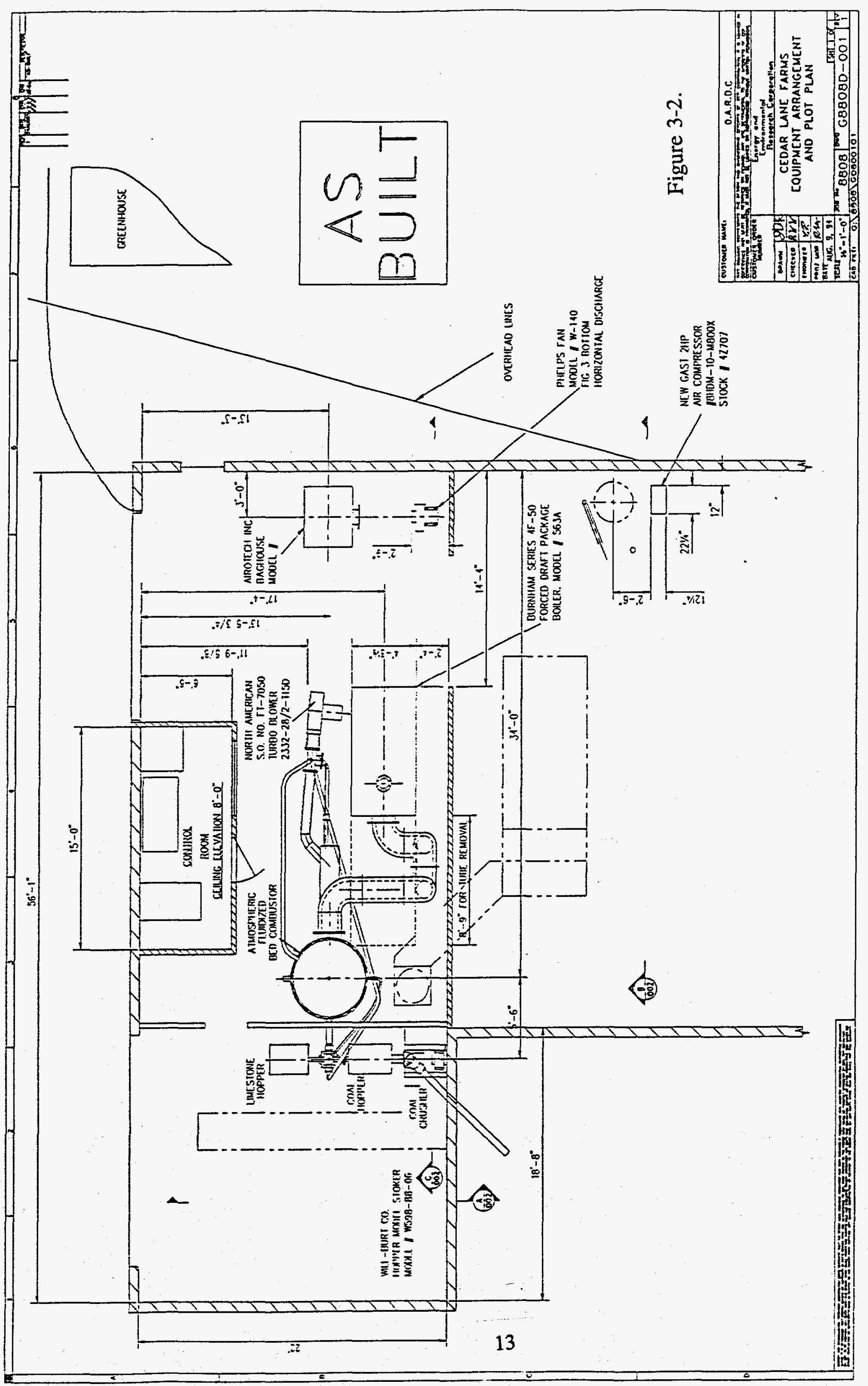


blower where it mixes mixed with recycled flue gas. The rate of fresh air is controlled to maintain a set oxygen percentage in the flue gas exiting the fluid bed. The recycled flue gasfresh air mix enters the windbox of the fluidized bed combustor and flows up through air distributor caps on the grid plate that supports the inert sand bed, providing the proper velocity to fluidize the bed.

The recirculated water returning from the greenhouses enters the hot water heater at $120^{\circ} \mathrm{F}$ and is heated up to $160^{\circ} \mathrm{F}$ prior to flowing back to the greenhouses for space heating. Mass and energy balances for the demonstration unit are shown in Table 3-1a,b,c,d. The piping and instrument diagram for the Cedar Lane Farms AFBC system is shown in Figure 3-3.

\subsection{Operations Assessment}

The operation of the AFBC has been very successful in meeting the cyclical heating demand loads of the greenhouse. Because there are no heat exchanger tubes in the bed proper, it can be banked for five to six hours during the day when the heating demand is low and restarted with no auxiliary fuel. Cedar Lane Farms personnel are impressed with the operation and intends to use the AFBC as a first on last off unit, in lieu of running their natural gas fired hot water heater.

\subsubsection{AFBC Control System}

The atmospheric fluidized bed combustion system was installed, started up and operated for extended periods of time at the CLF facility. Originally it was assumed that the control system used during the pilot testing at the OARDC would be used again at CLF. While discussing operations with CLF during the engineering phase, it became evident that the mostly manual control system at OARDC would not be sufficient to allow the AFBC to operate in the cyclical operational mode required by the greenhouse.

The CLF application required that the AFBC operate automatically as the demand for hot water varied throughout the day. The AFBC needed to be controlled so that it could shutdown and start backup automatically with little to no operator attention. During the spring months when the heat load is very cyclical, on-off cycling could occur five or six times in a 24-hour period. 
TABLE 3-1 a MASS AND ENERGY BALANCE

$2.2 \mathrm{MM}$ Btu/hr Ohio Coal Fired

\{COMBUSTION ZONE]

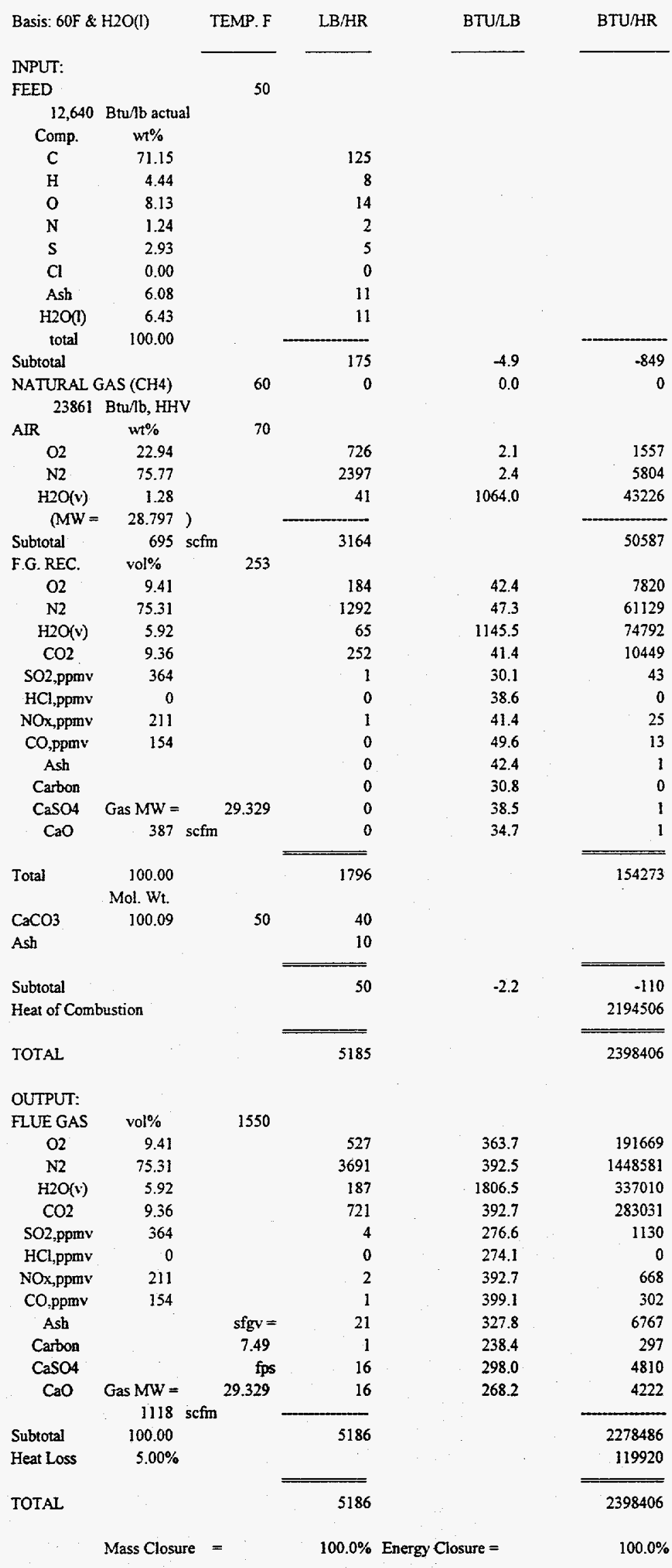




\begin{tabular}{|c|c|c|c|c|c|c|}
\hline & & & & $\begin{array}{l}\text { Air Leakage = } \\
\text { Cooling Water }=\end{array}$ & $\begin{array}{l}0.00 \% \\
107.6\end{array}$ & $\begin{array}{l}\text { Ctrl. Air } \\
\text { gpm }\end{array}$ \\
\hline Basis: $60 \mathrm{~F} \& \mathrm{H}$ & $20(1)$ & TEMP. F & $\mathrm{LB} / \mathrm{HR}$ & BTU/LB & & BTU/HR \\
\hline INPUT: & & & & & & \\
\hline FLUE GAS & vol $\%$ & 1550 & & & & \\
\hline $\mathrm{O} 2$ & 9.41 & 10.00 & 527 & 363.7 & & 191669 \\
\hline $\mathrm{N} 2$ & 75.31 & dry & 3691 & 392.5 & & 1448581 \\
\hline $\mathrm{H} 2 \mathrm{O}(\mathrm{v})$ & 5.92 & & 187 & 1806.5 & & 337010 \\
\hline $\mathrm{CO} 2$ & 9.36 & & 721 & 392.7 & & 283031 \\
\hline $\mathrm{SO} 2, \mathrm{ppmv}$ & 364 & & 4 & 276.6 & & 1130 \\
\hline $\mathrm{HCl}$,ppmv & 0 & & 0 & 342.8 & & 0 \\
\hline NOx,ppmv & 211 & & 2 & 392.7 & & 668 \\
\hline $\mathrm{CO}, \mathrm{ppmv}$ & 154 & & 1 & 399.1 & & 302 \\
\hline Ash & & & 21 & 327.8 & & 6767 \\
\hline Carbon & & & 1 & 238.4 & & 297 \\
\hline $\mathrm{CaSO} 4$ & & & 16 & 298.0 & & 4810 \\
\hline $\mathrm{CaO}$ & & & 16 & 268.2 & & 4222 \\
\hline$(M W=$ & 29.329 & ) & - & & & 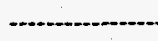 \\
\hline Subtotal & 100.00 & & 5186 & & & 2278486 \\
\hline COOLING WA & TER & 107 & & & & \\
\hline $\mathrm{H} 2 \mathrm{O}(\mathrm{l})$ & & & 53816 & 47.0 & & 2529352 \\
\hline AIR LEAK. & $w t \%$ & 70 & & & & \\
\hline $\mathrm{O} 2$ & 22.94 & & 0 & 2.1 & & 0 \\
\hline N2 & 75.77 & & 0 & 2.4 & & 0 \\
\hline $\mathrm{H} 2 \mathrm{O}(\mathrm{v})$ & 1.28 & & 0 & 1064.0 & & 0 \\
\hline$(\mathrm{MW}=$ & 28.797 & ) & (2........... & & & (n............ \\
\hline Subtotal & 0 & $\mathrm{scfm}$ & 0 & & & 0 \\
\hline TOTAL & & & 59002 & & & 4807838 \\
\hline OUTPUT: & & & & & & \\
\hline FLUE GAS & vol\% & 335 & & & & \\
\hline $\mathrm{O} 2$ & 9.41 & & 527 & 61.1 & & 32187 \\
\hline $\mathrm{N} 2$ & 75.31 & & 3691 & 67.9 & & 250559 \\
\hline $\mathrm{H} 2 \mathrm{O}(v)$ & 5.92 & & 187 & 1183.2 & & 220731 \\
\hline $\mathrm{CO} 2$ & 9.36 & & 721 & 60.1 & & 43351 \\
\hline $\mathrm{SO} 2, \mathrm{ppmv}$ & 364 & & 4 & 43.6 & & 178 \\
\hline $\mathrm{HCl} . \mathrm{ppmv}$ & 0 & & 0 & 55.6 & & 0 \\
\hline NOx,ppmv & 211 & & 2 & 60.1 & & 102 \\
\hline CO,ppmv & 154 & & 1 & 70.3 & & 53 \\
\hline Ash & & & 21 & 60.5 & & 1249 \\
\hline Carbon & & & 1 & 44.0 & & 55 \\
\hline $\mathrm{CaSO} 4$ & & & 16 & 55.0 & & 888 \\
\hline $\mathrm{CaO}$ & & & 16 & 49.5 & & 779 \\
\hline$(\mathrm{MW}=$ & 29.329 & ) & $\cdots$ & & & $\ldots$ \\
\hline Subtotal & 100.00 & & 5186 & & & 550132 \\
\hline HOT WATER & & 137 & & & & \\
\hline $\mathrm{H} 2 \mathrm{O}(\mathrm{l})$ & & & 53816 & 77.0 & & 4143832 \\
\hline Blowdown@0 & $.0 \%$ & 137 & 0 & 77.0 & & 0 \\
\hline Heat Loss & $5.00 \%$ & & & & & 113874 \\
\hline TOTAL & & & 59002 & & & 4807838 \\
\hline & Lass Closu & are $=$ & $100.0 \%$ & Energy Closure $=$ & & $100.0 \%$ \\
\hline
\end{tabular}


TABLE 3-1c MASS AND ENERGY BALANCE

2.2 MM Btu/hr Ohio Coal Fired

\{BAG HOUSE\}

EFFICIENCY $=$

\begin{abstract}
TEMP.F
\end{abstract}
LB/HR

335

FLUE GAS

$\mathrm{O} 2$

$\mathrm{N} 2$

$\mathrm{H} 2 \mathrm{O}(\mathrm{v})$

$\mathrm{CO} 2$

$\mathrm{SO} 2$,ppmv

$\mathrm{HCl}, \mathrm{ppmv}$

NOx,ppmv

CO,ppmv

Ash

Carbon

$\mathrm{CaSO} 4$

$\mathrm{CaO}$

$(\mathrm{MW}=$

TOTAL

29.329 )

100.00
9.41

75.31

5.92

9.36

364

0

211

154
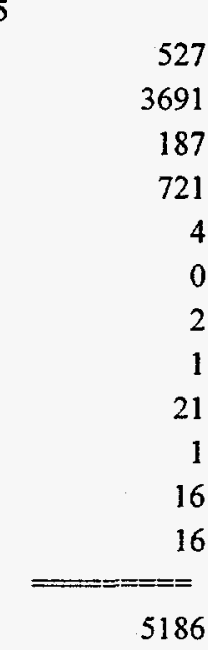

OUTPUT:

FLUE GAS

$\begin{array}{cr}\mathrm{O} 2 & 9.41 \\ \mathrm{~N} 2 & 75.31 \\ \mathrm{H} 2 \mathrm{O}(\mathrm{v}) & 5.92 \\ \mathrm{CO} 2 & 9.36 \\ \mathrm{SO} 2, \mathrm{ppmv} & 364 \\ \mathrm{HCl}, \mathrm{ppmv} & 0 \\ \mathrm{NOx}, \mathrm{ppmv} & 211 \\ \mathrm{CO}, \mathrm{ppmv} & 154 \\ \text { Ash } & \\ \text { Carbon } & \end{array}$

$\mathrm{CaSO} 4$

$\mathrm{CaO}$

$$
(\mathrm{MW}=
$$

Subtotal

29.329 )

100.00

253
$10.00 \%$

dry

527

3691

187

721

4

0

2

1

0

0

0

0

5132

253

B.H. SOLIDS

Ash

Carbon

$\mathrm{CaSO} 4$

$\mathrm{CaO}$

Subtotal

Heat Loss

$19.50 \%$

TOTAL

s


TABLE 3-1d MASS AND ENERGY BALANCE

2.2 MM Btu'hr Ohio Coal Fired

\{FLUE GAS RECYCLE\}

Flue Gas Recycle@

$35.0 \%$

\begin{tabular}{|c|c|c|}
\hline Basis: $60 \mathrm{~F} \&$ & $20(1)$ & TEMP. \\
\hline INPUT: & & \\
\hline FLUE GAS & vol $\%$ & 25 \\
\hline $\mathrm{O} 2$ & 9.41 & 10.00 \\
\hline N2 & 75.31 & $d$ \\
\hline $\mathrm{H}_{2} \mathrm{O}(\mathrm{v})$ & 5.92 & \\
\hline $\mathrm{CO} 2$ & 9.36 & \\
\hline SO2,ppmv & 364 & \\
\hline $\mathrm{HCl}$, ppmv & 0 & \\
\hline NOx,ppmv & 211 & \\
\hline $\mathrm{CO}, \mathrm{ppmv}$ & 154 & \\
\hline Ash & & \\
\hline Carbon & & \\
\hline $\mathrm{CaSO} 4$ & & \\
\hline $\mathrm{CaO}$ & & \\
\hline$(\mathrm{MW}=$ & $\begin{array}{r}29.329 \\
1107\end{array}$ & $\begin{array}{l}\text { ) } \\
\text { scfm }\end{array}$ \\
\hline
\end{tabular}

TOTAL

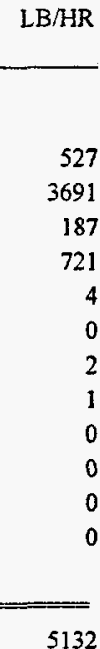

BTU/LB

BTU/HR

$\begin{array}{cr}\text { F.G. REC. } & \text { vol\% } \\ \mathrm{O} 2 & 9.41 \\ \mathrm{~N} 2 & 75.31 \\ \mathrm{H} 2 \mathrm{O}(\mathrm{v}) & 5.92 \\ \mathrm{CO} 2 & 9.36 \\ \mathrm{SO} 2, \mathrm{ppmv} & 364 \\ \mathrm{HCl}, \mathrm{ppmv} & 0 \\ \mathrm{NOx}, \mathrm{ppmv} & 211 \\ \mathrm{CO}, \mathrm{ppmv} & 154 \\ \text { Ash } & \\ \mathrm{Carbon} & \\ \mathrm{CaSO} 4 & \\ \mathrm{CaO} & \\ \text { (MW }= & 29.329 \text { ) } \\ & 387 \text { scfm }\end{array}$

253

184
1292
65
252
1
0
1
0
0
0
0
0

$\begin{array}{rr}42.4 & 22343 \\ 47.3 & 174655 \\ 1145.5 & 213693 \\ 41.4 & 29853 \\ 30.1 & 123 \\ 38.6 & 0 \\ 41.4 & 70 \\ 49.6 & 38 \\ 42.4 & 3 \\ 30.8 & 0 \\ 38.5 & 2 \\ 34.7 & 2\end{array}$

Subtotal

1796

440780

STACK vol\% 253

$\begin{array}{crrr}\mathrm{O} 2 & 9.41 & 10.00 \% & 3 \\ \mathrm{~N} 2 & 75.31 & \mathrm{~d} y & 2399 \\ \mathrm{H} 2 \mathrm{O}(\mathrm{v}) & 5.92 & & 121 \\ \mathrm{CO} 2 & 9.36 & & 468 \\ \mathrm{SO} 2, \mathrm{ppmv} & 364 & & \\ \mathrm{HCl}, \mathrm{ppmv} & 0 & & \\ \mathrm{NOx}, \mathrm{ppmv} & 211 & 0.5 & \\ \mathrm{CO}, \text { ppmv } & 154 & \mathrm{lb} / \mathrm{MM} \text { Btu }\end{array}$

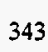

2399

42.4

42.4

47.3

1145.5

41.4

30.1

38.6

41.4

49.6

42.4

30.8

38.5

34.7

.

343
655
693
853
123
0
70
38
3
0
2
2

0

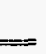

Ash

Carbon

$\mathrm{CaSO} 4$

$\mathrm{CaO}$

$(\mathrm{MW}=29.329)$

$719 \mathrm{sefm}$

Subtotal

3336

121
468

47.3

1145.5

41.4

30.1

38.6

41.4

49.6

42.4

30.8

38.5

34.7

7820

61129

74792

10449

43

0

25

13

1

I

1

154273

14523

113525

138900

19404

80

0

46

24

2

1

1

TOTAL

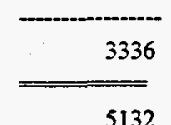

286507

440780

Mass Closure =

100.0\% Energy Closure $=$

$100.0 \%$

OPERATIONS SUMMARY

$\begin{array}{lrl}\text { Sulfur In } & 4.63 \text { lb SO2/MM Btu } \\ \text { Sulfur Out } & 1.20 \text { lb SO2/MM Btu } \\ \text { NOx = } & 0.5 \text { lb NO2/MM Btu } \\ \text { Particulate } & 0.05 \mathrm{lb} / \mathrm{MM} B t a\end{array}$
SO2 Removal

$\mathrm{Ca} / \mathrm{S}$ Ratio Estimate

Thermal Efficiency

Flue Gas Recycle $=\quad 74.1 \%$

$=\quad 2.5$

$=\quad 73.0 \%$

$=\quad 35.0 \%$ 
A decision was made to convert the control system to a programmable logic control (PLC) system that could handle the sequential starting, stopping and banking as well as the modulating control of the AFBC when operating. With the new control system at CLF, the system will start up, shut down and bank itself automatically. The combustor will stay in a banked condition without a need for fuel for some five to six hours, a feature very important to meet the cyclical demand load for greenhouse heating and other small industrial heating applications.

The system requires very little operator attention; it runs on primarily on automatic control. The only operator function normally required is the turning on of the eductor that removes fly ash/sorbent buildup from the heat exchanger fire box and transports it to the baghouse hopper. This is required to be performed once a day. Combustor operation to date has been very successful. A few upgrades were implemented during the long term test program to make it more commercially acceptable.

This particular AFBC uses a sand bed as the fluidizing media and has no internal heat transfer surfaces. With this AFBC there have been no ash-calcium agglomerates formed in the bed. All of the ash and sorbent are blown from the combustor to a downstream baghouse. The baghouse catch drum has been equipped with an automated ash screw that removes the fly ash/sorbent from the catch drum on level control. This feature eliminated the need for the operators to manually dump the catch drum. It reduces the risk of an operator being burned with hot ash and also operating labor costs somewhat.

\subsubsection{AFBC Electrical Service}

At the start of construction it was believed that sufficient electrical power was available within the existing electrical service at CLF. It became clear during the detailed engineering phase of the project that the existing service was not adequate to handle the additional load requirements of the AFBC system. The existing service consisted of a 400-amp main system that was split through two $200 \mathrm{amp}$ subsystems. One subsystem supplied power to the west complex and the other supplied power to the east complex. The new boiler room was located adjacent to the existing boilers as part of the east complex. A close check of the power requirement of the east complex indicated that it was near capacity without the additional load requirement of the AFBC. 
CLF, EER, and Ohio Power decided to increase the main service to $600 \mathrm{amps}$. This provided ample power for all areas of the complex and supplied the requirements of the AFBC installation. CLF shared some of the expanded electrical service costs. The new electrical service provided the power required and has performed well since installation.

\subsubsection{Coal Handling/Preparation}

The AFBC was installed alongside an existing underfeed coal stoker. Both units received coal from the same coal bin. A vibrating coal screen was installed to screen the $1 / 2$ " $\mathrm{x} 0$ " coal from the stoker coal normally received by CLF. At the time the decision was made to use a coal screen, CLF was experiencing problems with coal fines plugging in its underfeed coal stoker. The AFBC doesn't handle coal sizes above $1 / 2$ ", so screening was chosen as a practical approach to solve the stoker problem and also provide coal feed to the AFBC. The coal handling system was designed to convey coal from the coal bin to the screen. The screened coal would then fall into the AFBC coal feed hopper and the larger coal would be returned to the coal bin to supply a coarser coal feed to the stoker.

During the startup phase of the project it became apparent that the vibrating screen was not acceptable due to continued coal screen pluggage problems. In discussions between EER and the manufacturer it was determined that the screen would need to have major modifications to have a chance of working properly. Even if the modifications were made there would be no guarantee from the manufacturer that the screen would work. It was then decided to remove the screen and replace it with a small crusher that would reduce stoker coal size to the $-1 / 2$ " needed for the AFBC. The screen manufacturer allowed a partial credit for the return of the vibrating

screen. The coal crusher has performed satisfactorily, although the coal feed pipe has sporadically plugged when certain coal deliveries included coal that shears in planes during crushing. Thus, long slender coal particles of plus 1 " in length were formed that plated out in the coal pipe. A correction to this problem, will be to weld ribs on the crusher plates.

\subsubsection{Coal Feed System}

Originally it was expected that the $A \overline{F B C}$ coai feed system would be converted from a pneumatic top bed injection system to a bottom bed feed auger system. During completion of testing at OARDC, before pilot plant shutdown, it was determined that the auger system would not work. 
A modified bottom bed feed pneumatic system was then designed and installed, and the system worked well over several short duration test periods prior to shutting down the pilot plant operation. During the startup phase at CLF, certain limitations appeared in the bottom feed pneumatic system.

Unlike the OARDC application, at CLF the system had to startup and shutdown automatically and also run continuously over extended periods of time. The fuel transport line from the rotary airlock into the bottom of the fluid bed occasionally would plug. This required the operator to shutdown the system and clean out the pipe. The pluggage generally occurred during periods of low air flow, as the system was starting up or shutting down.

The other problem with the coal feed system was the tramp air leaking past the rotary airlock which would blow coal fines back through the coal and lime feed augers into the hoppers. These fines would build up in the lower part of the hoppers, above the feed augers, and cause bridging. The air leakage problem was solved by adding a vent line from the rotary airlock riser to the combustor at a point above the bed level. The combustor draft was increased to increase the effectiveness of the vent.

A low differential pressure switch was added to the transport air line to trip the coal feed system if the pressure dropped too low. This feature did not prevent feed pipe pluggage, but did prevent the airlock from becoming plugged, making clean out much easier. A clean out port was added to allow easier cleaning without completely shutting down the system. Several changes were made to the control system to decrease the possibility of low transport air flow. Although these modifications helped, it was finally decided to install a separate regenerative air blower for the coal feed system. This unit was installed and has performed much better.

\subsubsection{Boiler Ash Removal}

During engineering it was known that if a heat exchanger with horizontal tube passes was selected for the system that ash/sorbent plugging might be a problem due to the high particulate loading associated with the addition of limestone to the AFBC system. However, a horizontal tube standard hot water heater, was the least cost, and with the addition of automatic sootblowers, it appeared that the particulate problem would be minor. Further, the Will-Burt Company who is marketing the combustor recommended the horizontal boiler be used due to the 
potential it would add to the retro-fit market. Because of these considerations it was decided to use a conventional fire-box design similar to the existing coal stoker fired unit at CLF.

During the initial AFBC operation, it became evident that sorbent and ash were accumulating in the fire box of the hot water heater. The ash level increased in the fire box and eventually solids were carried over to the second pass tubes. The ash then began to settle out in the transition box between the second and third pass tubes where the sootblowers are located. Eventually the lower row of tubes became completely blocked with loose ash and sorbent.

EER corrected this problem by installing an eductor through the floor in the rear of the firebox. This eductor is run intermittently (once per day) to remove an excessive buildup of ash. The ash/sorbent is educted to the bag house for collection and disposal. The addition of this eductor system also provided the information required to evaluate the system for use on future retrofit applications. Will-Burt anticipates that one of the target markets for the combustor will be to retrofit existing boilers now using gas, oil, or older coal burning equipment.

\subsubsection{Dust Collector Cartridges}

The dust collector for this project included cartridges made of pleated Nomex felt with a GoreTex membrane covering. Nomex bags were used in the OARDC bag house during the pilot testing of the combustor. During the AFBC startup, a routine inspection of the cartridges showed an apparent deterioration of the Gore-Tex membrane on the cartridges.

Further investigation by the cartridge manufacturer, W.L. Gore, showed that the Nomex felt was actually deteriorating under the Gore-Tex membrane, allowing the membrane to break away from the felt. It was determined that the deterioration was a result of an acid attack from the cyclical operation of the AFBC, which allowed the temperature in the dust collector, during shutdown periods, to drop below the sulfuric acid dew point. W.L. Gore recommended replacing the Nomex cartridges with Ryton cartridges, an acid resistant felt with a Gore-Tex membrane. The new cartridges have resisted acid attack and have performed satisfactorily since installation. 


\subsubsection{Fly Ash/Spent Sorbent from Dust Collector}

After startup, it was determined that the manual removal of fly ash/sorbent from the catch drum under the dust cartridge was difficult for one operator to remove and dump, and on the afternoon and midnight shifts at the greenhouse there is only one person attending the greenhouse operations. A small automatic ash removal system was installed that includes a screw that transports the ash/spent sorbent from the catch drum to an outside storage bin. The drum is equipped with a level switch to automatically start and stop the screw, and an air pulse was provided to the catch drum to break up bridging. The system was fairly low in cost, is operating well and has reduced operator attention requirements.

\subsubsection{Induced Draft Fan}

Upon initial startup, the AFBC throughput was limited by the flow rate capacity of the induced draft (ID) fan. It was necessary to limit the total mass flow of air and recycle flue gas through the combustor to maintain a negative draft on the system. The system is using the same ID fan that was used on the pilot project that was designed for a coal feed rate input of $1.5 \times 10^{6} \mathrm{Btu} / \mathrm{hr}$. The CLF system is capable of firing $2.25 \times 10^{6} \mathrm{Btu} / \mathrm{hr}$ of coal. However, at such a rate when the dust collector pressure drop increased beyond a 4 " water column value, at times the AFBC would go slightly positive in pressure due to the limited ID fan capacity. The horsepower of the motor was checked and it was possible to change the shivs on the ID fan to speed up the fan to provide more capacity and still be within the required motor size.

\subsection{Data Analyses}

In the long term operation of the AFBC at Cedar Lane Farms (CLF) data were collected and analyzed during normal operating conditions. The results of the CLF data are also compared with the results from the pilot scale operation at OARDC.

\subsubsection{Coal and Sorbent}

Over the testing period one coal and two limestones were tested, see Table 3-2. Currently, the calcitic limestone supplied by National Lime and Stone is being used at Cedar Lane Farms. 


\section{TABLE 3-2. Coal and Limestone Analyses}

Coal Delivered: Wayne Mine Ohio Bituminous, size 2" x 0" unwashed Ultimate Analysis

$\begin{array}{lr}\text { Component } & \text { Wt } \% \\ \mathrm{SiO}_{2} & 41.46 \\ \mathrm{Al}_{2} \mathrm{O}_{3} & 24.26 \\ \mathrm{TiO}_{2} & 1.08 \\ \mathrm{Fe}_{2} \mathrm{O}_{3} & 26.95 \\ \mathrm{CaO} & 2.00 \\ \mathrm{MgO} & 0.82 \\ \mathrm{Na} \mathrm{O}_{2} \mathrm{O} & 0.46 \\ \mathrm{~K}_{2} \mathrm{O} & 1.80 \\ \mathrm{P}_{2} \mathrm{O}_{5} & 0.28 \\ \mathrm{SrO} & 0.06 \\ \mathrm{BaO} & 0.00 \\ \mathrm{MnO} 2 & 0.13 \\ \mathrm{Other} & 0.36 \\ \text { Total } & 100.00\end{array}$

$\begin{array}{lr}\text { Component } & \text { Wt } \% \\ \text { Carbon } & 71.15 \\ \text { Hydrogen } & 4.44 \\ \text { Oxygen } & 8.13 \\ \text { Nitrogen } & 1.24 \\ \text { Sulfur } & 2.93 \\ \text { Moisture } & 5.68 \\ \text { Ash } & 6.43 \\ \text { Total } & 100.00\end{array}$

Higher Heating Value:

$\mathrm{HHV}=12,640 \mathrm{Btu} / \mathrm{lb}$

Coal Sulfur $=4.63 \mathrm{lb} \mathrm{SO}_{2} /$ million Btu

Calculated $\mathrm{Ca} / \mathrm{S}$ ratio of ash $=0.04$

where, $\mathrm{Ca}=\mathrm{Ca}+\mathrm{Na}_{2}+\mathrm{K}_{2}$

Wt \%

4.44

8.13

2.93

5.68

100.00

Limestone Delivered (Chemical and Physical Analyses):

National Lime and Stone

Calcium carbonate $\left(\mathrm{CaCO}_{3}\right)$

Magnesium carbonate $\left(\mathrm{MgCO}_{3}\right)$

Insolubles

Iron oxide $\left(\mathrm{Fe}_{2} \mathrm{O}_{3}\right)$

Sulfur as $\mathrm{SO}_{3}$

Total

80.00

17.00

2.55

0.20

$\frac{0.25}{100.00}$

Loss on Ignition

Bulk Density
$44 \mathrm{wt} \%$

$95 \mathrm{lb} / \mathrm{cu} . \mathrm{ft}$.
Ohio Lime Company

Calcium carbonate $\left(\mathrm{CaCO}_{3}\right)$

Magnesium carbonate $\left(\mathrm{MgCO}_{3}\right)$

Insolubles

Sulfur as $\mathrm{SO}_{3}$

Moisture

Total

Loss on Ignition $\quad 47.2 \mathrm{wt} \%$

Bulk Density
54.40

1.34

0.06

0.10

$\frac{0.10}{100.00}$

$87.9 \mathrm{lb} / \mathrm{cu} . \mathrm{ft}$.

Tables 3-3 and 3-4 show the test results for the combustion of Ohio coal using dolomitic limestone as the $\mathrm{SO}_{2}$ sorbent at $\mathrm{Ca} / \mathrm{S}$ ratios of 2.5 and 1.75 respectively. Table 3-5 shows the test results for the combustion of Ohio coal using calcitic limestone as the $\mathrm{SO}_{2}$ sorbent at a $\mathrm{Ca} / \mathrm{S}$ ratio of 2.5. The coal, dolomitic and calcitic limestone analyses were the same as that used for the test work at OARDC.

\subsubsection{Sulfur Dioxide Capture}

The Ohio coal being fired during the testing of the Cedar Lane Farms system was slightly different from the coal analysis shown in Table 3-1. It had a sulfur content of $3.0 \mathrm{wt} \%$ and a higher heating value of $12,650 \mathrm{Btu} / \mathrm{lb}$ which translates to $4.74 \mathrm{lb} \mathrm{SO}_{2} / \mathrm{million}_{\mathrm{Btu}}$. The best 
TABLE 3-3. Cedar Lane Farms AFBC Data

Dolomitic Limestone used to Capture $\mathrm{SO}_{2}$

\begin{tabular}{|c|c|c|c|c|c|c|c|c|}
\hline Date: & $4 / 7 / 95$ & $4 / 7 / 95$ & $4 / 8 / 95$ & $4 / 8 / 95$ & $4 / 22 / 95$ & $4 / 23 / 95$ & $4 / 23 / 95$ & $4 / 24 / 95$ \\
\hline Time: & $17: 45-18: 45$ & 19:20-20:20 & $00: 00-03: 50$ & 04:40-08:40 & 19:59-23:59 & 00:00-04:00 & 04:00-08:00 & 04:00-08:00 \\
\hline \multicolumn{9}{|l|}{ Fluid Bed Combustor: } \\
\hline Coal leed ratc, $16 / h r$ & 191 & 191 & 152 & 152 & 142 & 137 & 140 & 137 \\
\hline Coal feed rate, MM Btu/hr & 2.42 & 2.42 & 1.92 & 1.92 & 1.80 & 1.73 & 1.77 & 1.73 \\
\hline Limestone" " leed rate, lh/hr & 82 & 82 & 65 & 65 & 61 & 59 & 60 & 59 \\
\hline Ca/S molar ratio & 2.5 & 2.5 & 2.5 & 2.5 & 2.5 & 2.5 & 2.5 & 2.5 \\
\hline Calcium utilization & 30.1 & 30.1 & 27.9 & 27.9 & 31.0 & 30.2 & 29.5 & 27.0 \\
\hline Combustor outlet temperature, F & 1477 & 1477 & 1553 & 1553 & 1552 & 1551 & 1544 & 1550 \\
\hline \multicolumn{9}{|l|}{ Hot Water Heator: } \\
\hline Outlet llue gas temperature, $F$ & 346 & 346 & 360 & 374 & 335 & 337 & 345 & 351 \\
\hline Water inlet temperature, $F$ & 116 & 116 & 127 & 127 & 114 & 115 & 121 & 130 \\
\hline Water outlet temperature, $F$ & 156 & 156 & 166 & 166 & 137 & 135 & 144 & 156 \\
\hline Water rate, $\mathrm{lb} / \mathrm{hr}$ & 32,500 & 32,500 & 34,000 & 34,000 & 51,000 & 51,500 & 48,000 & 46,500 \\
\hline Hoat to water, MM Btu/hr & 1.30 & 1.30 & 1.33 & 1.33 & 1.17 & 1.03 & 1.10 & 1.21 \\
\hline Thermal elficiency. $\%$ & $53.80 \%$ & $53.80 \%$ & $68.96 \%$ & $68.96 \%$ & $65.30 \%$ & $59.43 \%$ & $62.34 \%$ & $69.76 \%$ \\
\hline \multicolumn{9}{|l|}{ Fluo Gns Composition: } \\
\hline Oxyuen, vol \% & 10.1 & 10.1 & 9.4 & 9.4 & 8.6 & 8.5 & 8.4 & 8.0 \\
\hline Carbon Dioxide, vol \% & 9.4 & 9.4 & 10.1 & 10.1 & 11.0 & 11.1 & 11.2 & 10.7 \\
\hline Carbon Monoxide, ppmv & 213 & 213 & 205 & 205 & 180 & 126 & 121 & 104 \\
\hline Sulfur Dioxide, ppmv & 370 & 370 & 481 & 481 & 382 & 607 & 452 & 581 \\
\hline Nitrogen Oxides, ppmv & 385 & 385 & 332 & 332 & 289 & 254 & 244 & 214 \\
\hline \multicolumn{9}{|l|}{ Air Emissions: } \\
\hline SO2. Ib/MM Btu (Base" " & 4.74 & 4.74 & 4.74 & 4.74 & 4.74 & 4.74 & 4.74 & 4.74 \\
\hline $\mathrm{SO} 2,1 \mathrm{~b} / \mathrm{MM} \mathrm{Biu}$ & 1.18 & 1.18 & 1.44 & 1.44 & 1.07 & 1.17 & 1.25 & 1.54 \\
\hline $\mathrm{NOx}, \mathrm{lb} / \mathrm{MM} \mathrm{Btu}$ & 0.89 & 0.89 & 0.72 & 0.72 & 0.59 & 0.51 & 0.49 & 0.41 \\
\hline
\end{tabular}

- Coal sulfur @ 3.0wt\%

- Dolomitic limesione@ $21.82 \%$ Ca. 20 x 100 mesh

.. Fired in a conventional burner with no sulfur capture 
TABLE 3-4. Cedar Lane Farms AFBC Data

Dolomitic Limestone used to Capture $\mathrm{SO}_{2}$

\begin{tabular}{|c|c|c|c|c|c|c|c|c|c|}
\hline Data: & $5 / 3 / 95$ & $5 / 3 / 95$ & $5 / 4 / 95$ & $5 / 5 / 95$ & $5 / 6 / 95$ & $5 / 6 / 95$ & $5 / 6 / 95$ & $5 / 7 / 95$ & $5 / 7 / 95$ \\
\hline Time: & $00: 00-04: 00$ & 04:00-08:00 & 19:59-23:59 & $02: 30-06: 30$ & 01:00-04:00 & $04: 00-08: 00$ & $20: 59-23: 59$ & $00: 00-04: 00$ & $04: 00-08: 00$ \\
\hline \multicolumn{10}{|l|}{ Fluid Bed Combustor: } \\
\hline Coal ${ }^{\circ}$ food rato, $1 \mathrm{~b} / \mathrm{hr}$ & 137 & 132 & 121 & 121 & 135 & 139 & 146 & 146 & 146 \\
\hline Coal lood rata, MM Btu/hr & 1.73 & 1.67 & 1.53 & 1.63 & 1.71 & 1.76 & 1.83 & 1.86 & 1.85 \\
\hline Limostono" lood rato, $\mathrm{lb} / \mathrm{hr}$ & 41 & 40 & 36 & 36 & 41 & 42 & 44 & 14 & 44 \\
\hline Ca/s molar ratio & 1.75 & 1.76 & 1.76 & 1.76 & 1.76 & 1.70 & 1.76 & 1.76 & 1.76 \\
\hline Calcium utilization & 39.2 & 38.9 & 39.6 & 41.9 & 39.8 & 39.6 & 39.9 & 40.3 & 40.8 \\
\hline Combustor oullet temperature. & 1650 & 1563 & 1653 & 1563 & 1652 & 1562 & 1562 & 1562 & 1563 \\
\hline \multirow{2}{*}{\multicolumn{10}{|c|}{ Hot Wntor Hontar: }} \\
\hline & & & & & & & & & \\
\hline Oullat llue gas iompornturn, $F$ & 351 & 333 & 352 & 362 & 343 & 337 & 342 & 311 & 341 \\
\hline Water inlel tomperature, $F$ & 130 & 114 & 136 & 136 & 121 & 114 & 109 & 114 & 117 \\
\hline Water outlot tomparaturo, $F$ & 156 & 134 & 169 & 169 & 161 & 139 & 146 & 143 & 144 \\
\hline Wator rato, lb/hr & 46,600 & 51,000 & 34.600 & 34,500 & 43.000 & 46,600 & 36.600 & 46,600 & 44,000 \\
\hline Heat to wator, MM Btu/hr & 1.21 & 1.02 & 1.14 & 1.14 & 1.29 & 1.14 & 1.31 & 1.32 & 1.19 \\
\hline Thermal officiency. $\%$ & $69.76 \%$ & $61.09 \%$ & $74.38 \%$ & $74.38 \%$ & $76.64 \%$ & $64.69 \%$ & $71.61 \%$ & $71.44 \%$ & $64.32 \%$ \\
\hline \multicolumn{10}{|l|}{ Flun Gas Composition: } \\
\hline Oxygon, vol \% & 9.3 & 9.3 & 8.8 & 9.0 & 9.1 & 9.3 & 9.1 & 9.1 & 9.2 \\
\hline Carbon Dioxida, vol \% & 9.9 & 9.7 & 9.7 & 9.6 & 10.0 & 9.8 & 9.8 & 9.8 & 9.8 \\
\hline Carbon Monoxide. ppmv & 149 & 166 & 108 & 120 & 137 & 141 & 134 & 161 & 166 \\
\hline Sulfur Dioxido, ppmv & 504 & 511 & 613 & 439 & 493 & 492 & 492 & 479 & 463 \\
\hline Nitrogen Oxidos, ppmv & 268 & 245 & 372 & 372 & 269 & 245 & 291 & 260 & 233 \\
\hline \multicolumn{10}{|l|}{ Air Emissions: } \\
\hline SO2, Ib/MM Biu (Base *" ") & 4.74 & 4.74 & 4.74 & 4.74 & 4.74 & 4.74 & 4.74 & 4.74 & 4.74 \\
\hline SO2, Ib/MM Blu & 1.49 & 1.62 & 1.46 & 1.26 & 1.44 & 1.46 & 1.43 & 1.40 & 1.36 \\
\hline NOx, lb/MM Btu & 0.67 & 0.63 & 0.76 & 0.76 & 0.65 & 0.53 & 0.61 & 0.63 & 0.60 \\
\hline
\end{tabular}

- Coal sulfur @ 3.0wt\%

- Dolornitic limestone @ 21.82\% Ca, $20 \times 100$ mesh

- * Fired in a conventional burner with no sulfur copture 
TABLE 3-5. Cedar Lane Farms AFBC Data

Calcitic Limestone used to Capture $\mathrm{SO}_{2}$

\begin{tabular}{|c|c|c|c|c|c|c|c|c|c|}
\hline Date: & $5 / 12 / 95$ & 5/13/95 & $5 / 15 / 95$ & $5 / 16 / 95$ & $5 / 17 / 95^{*}$ & $5 / 18 / 95$ & $5 / 18 / 95$ & $5 / 18 / 95$ & $5 / 19 / 95$ \\
\hline Time: & 21:00-23:00 & 00:00.06:30 & 21:00-23:00 & 01:00-06:15 & $00: 49-02: 41$ & 01:15-07:00 & 11:00-15:00 & 16:00-20:00 & $01: 00-05: 00$ \\
\hline Fluid Bed Combustor: & & & & & & & & & \\
\hline Coal" " feed rate, $1 \mathrm{~b} / \mathrm{hr}$ & 147 & 143 & 176 & 175 & 186 & 150 & 149 & 138 & 126 \\
\hline Cool food rate, MM Btu/hr & 1.86 & 1.81 & 2.21 & 2.21 & 2.36 & 1.90 & 1.88 & 1.76 & 1.59 \\
\hline Limestone " " feed rale, $\mathrm{lb} / \mathrm{hr}$ & 30 & 29 & 36 & 36 & 38 & 31 & 31 & 28 & 26 \\
\hline $\mathrm{Ca} / \mathrm{S}$ molar ratio & 1.75 & 1.75 & 1.75 & 1.75 & 1.76 & 1.76 & 1.75 & 1.75 & 1.75 \\
\hline Calcium utilization & 46.8 & 49.3 & 47.1 & 51.6 & 50.2 & 50.6 & 49.8 & 49.1 & 49.8 \\
\hline Combustor outlat temperature, & 1562 & 1554 & 1543 & 1545 & 1534 & 1652 & 1562 & 1552 & 1562 \\
\hline Hot Water Heater: & & & & & & & & & \\
\hline Outlet flue gas temperature, $F$ & 339 & 350 & 351 & 363 & 349 & 335 & 336 & 335 & 335 \\
\hline Water inlet temperature, $F$ & 106 & 127 & 119 & 122 & 113 & 103 & 92 & 109 & 104 \\
\hline Water outlet temperature, $F$ & 131 & 156 & 146 & 167 & 169 & 136 & 120 & 132 & 125 \\
\hline Wator rate, ib/hr & 60.600 & 29,500 & 47.000 & 27.000 & 23.000 & 33,600 & 47,600 & 50,000 & 51,000 \\
\hline Heat to water, MM Btu/hr & 1.26 & 0.83 & 1.27 & 0.95 & 1.06 & 1.11 & 1.33 & 1.15 & 1.07 \\
\hline Thermal efficiency, $\%$ & $67.89 \%$ & $45.66 \%$ & $57.32 \%$ & $42.69 \%$ & $44.97 \%$ & $58.26 \%$ & $70.66 \%$ & $66.88 \%$ & $67.19 \%$ \\
\hline Flue Gas Composition: & & & & & & & & & \\
\hline Oxygen, vol \% & 9.7 & 9.5 & 9.9 & 10.4 & 10.0 & 10.3 & 10.2 & 10.0 & 9.6 \\
\hline Carbon Dioxide, vol \% & 10.8 & 9.3 & 9.0 & 8.5 & 8.6 & 8.9 & 8.9 & 9.0 & 0.3 \\
\hline Carbon Monoxide, ppmv & 112 & 112 & 101 & 98 & 86 & 99 & 116 & 106 & 102 \\
\hline Sulfur Dioxide, ppmv & 279 & 219 & 279 & 143 & 186 & 173 & 190 & 211 & 203 \\
\hline Nitrogen Oxides, ppmv & 299 & 255 & 463 & 317 & 380 & 294 & 214 & 244 & 249 \\
\hline Air Emissions: & & & & & & & & & \\
\hline SO2, Ib/MM Btu (Base * **) & 4.74 & 4.74 & 4.74 & 4.74 & 4.74 & 4.74 & 4.74 & 4.74 & 4.74 \\
\hline SO2, $\mathrm{lb} / \mathrm{MM} \mathrm{Btu}$ & 0.86 & 0.66 & 0.84 & 0.46 & 0.58 & 0.56 & 0.61 & 0.67 & 0.61 \\
\hline NOX, Ib/MM Btu & 0.67 & 0.66 & 1.04 & 0.76 & 0.87 & 0.69 & 0.60 & 0.56 & 0.65 \\
\hline
\end{tabular}

- Skewed $\mathrm{Ca} / \mathrm{S}$ ratio so more limestone fed at lower rates

" Coal sulfur @ 3.0 wt\%

*.. Calcitic limestone @ $32.04 w t \%$ Ca, $12 \times 100$ mesh

.... Fired in a conventional burner with no sulfur capture 
temperature for sulfur dioxide capture when using dolomitic limestone as a sorbent appears to be in the range of 1500 to $1550^{\circ} \mathrm{F}$ (see Figure 3-4). Sulfur dioxide capture via dolomitic limestone addition at a $\mathrm{Ca} / \mathrm{S}$ ratio of 2.5 to the fluid bed yielded flue gas emission rates as low as $0.98 \mathrm{lb}$ of $\mathrm{SO}_{2}$ per million Btu of coal fired. This compares with emission rates of about 1.30 $\mathrm{lb}$ of $\mathrm{SO}_{2}$ per million Btu of coal fired with dolomitic limestone added at a $\mathrm{Ca} / \mathrm{S}$ ratio of 2.5 during the pilot work at OARDC. Figure 3-5 shows the effect on sulfur dioxide capture when feeding dolomitic limestone at rates to yield $\mathrm{Ca} / \mathrm{S}$ ratios of 1.75 and 2.5 . The data indicate that the regulated emission requirement of $1.2 \mathrm{lb}$ of $\mathrm{SO}_{2} / 10^{6} \mathrm{Btu}$ of coal fired could be met with a dolomitic limestone rate to yield a $\mathrm{Ca} / \mathrm{S}$ ratio of $\sim 2.0$.

The calcitic limestone performed even better at a $\mathrm{Ca} / \mathrm{S}$ ratio of 2.5 yielding flue gas emission rates as low as $0.44 \mathrm{lb}$ of $\mathrm{SO}_{2}$ per million Btu of coal fired (see Figure 3-5). This level compares with emission rates of about $2.0 \mathrm{lb}$ of $\mathrm{SO}_{2}$ per million Btu of coal fired using a $\mathrm{Ca} / \mathrm{S}$ ratio of 2.5 during the pilot work at OARDC. The combination of under bed coal feed and fly ash sorbent reinjection worked to improve the calcium utilization of both the dolomitic and calcitic limestones. This improved calcium utilization makes the AFBC somewhat more cost effective due to the reduced rate of limestone required.

\subsection{3 $\mathrm{NO}_{\mathrm{x}}$ Reduction}

The nitrogen oxide emission results for the runs are also shown in Tables 3-3, 3-4 and 3-5. Generally the NOx emissions were generally lower than that observed during pilot plant operation, ranging with from a low of 0.41 to $1.04 \mathrm{lb} \mathrm{NOx} / \mathrm{million}$ Btu.

In Figure 3-6, a correlation between carbon monoxide in the flue gas and NOx emissions is shown. The trend, like the pilot plant operation, shows that NOx emissions reduce with increased CO levels. During the use of the dolomitic limestone, the levels of NOx were lower when feeding limestone at the higher rate to achieve a $\mathrm{Ca} / \mathrm{S}$ ratio of 2.5, also see Figure 3-6. The limestone is also probably capturing some NOx as calcium nitrate in accord with the following reactions:

$$
\begin{gathered}
3 \mathrm{CaSO}_{3}+3 \mathrm{O}_{2}->3 \mathrm{CaSO}_{4}+3(\mathrm{O}) \\
\mathrm{CaO}+2 \mathrm{NO}+3(\mathrm{O})->\mathrm{Ca}\left(\mathrm{NO}_{3}\right)_{2}
\end{gathered}
$$




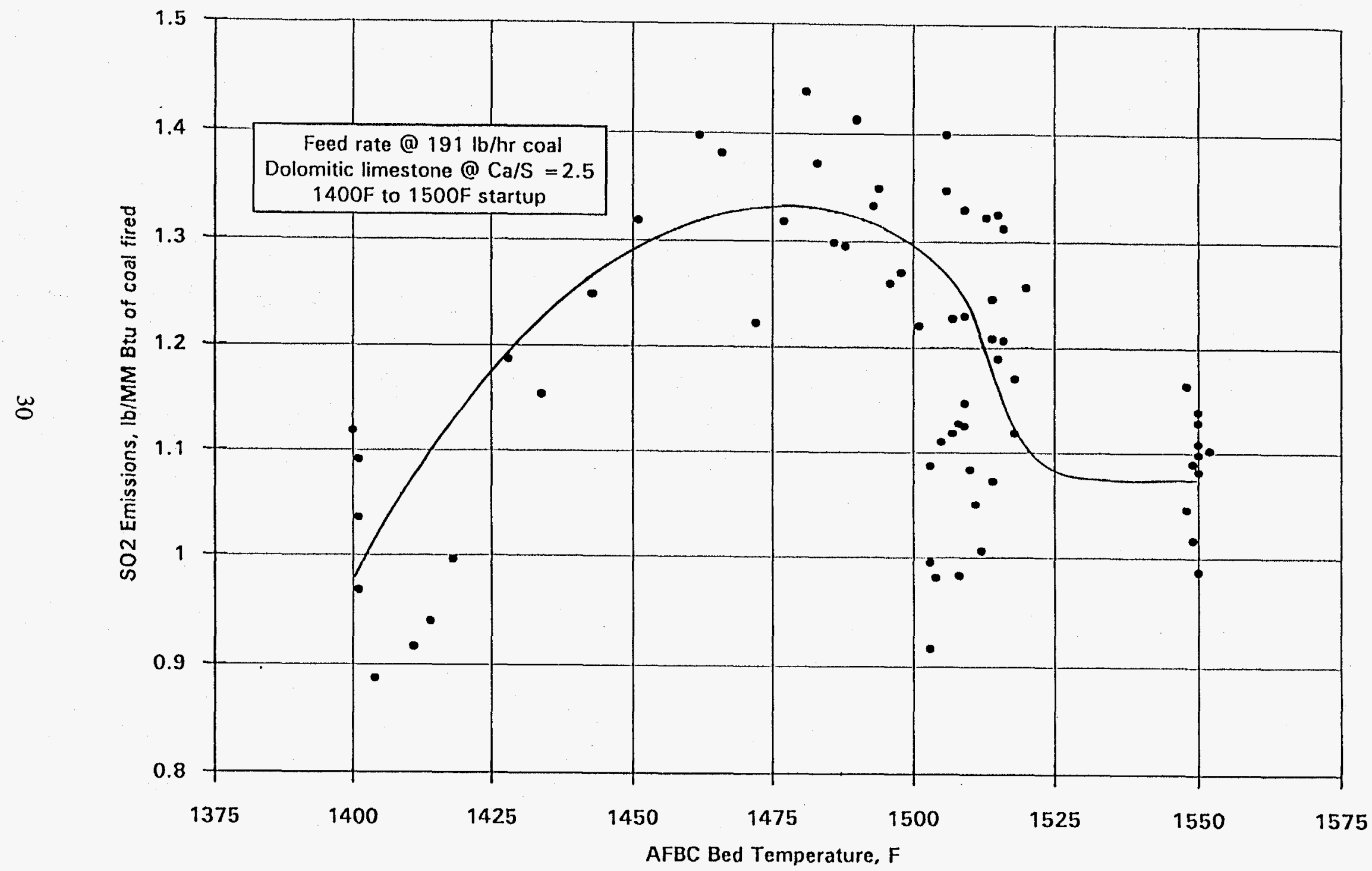

Figure 3-4. SO2 emissions versus fluid bed temperature 


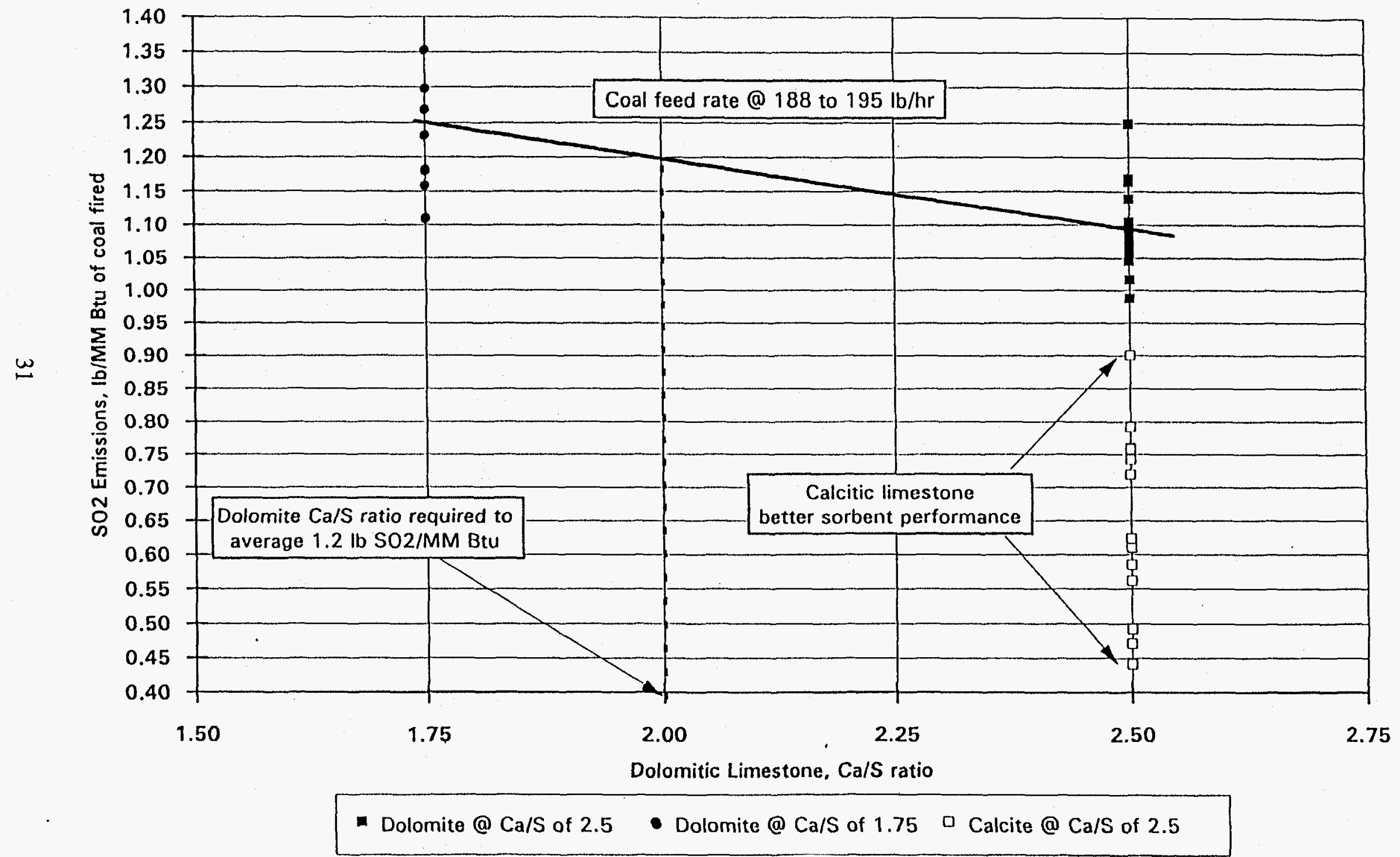

Figure 3-5. Sulfur dioxide capture versus $\mathrm{Ca} / \mathrm{S}$ ratio 


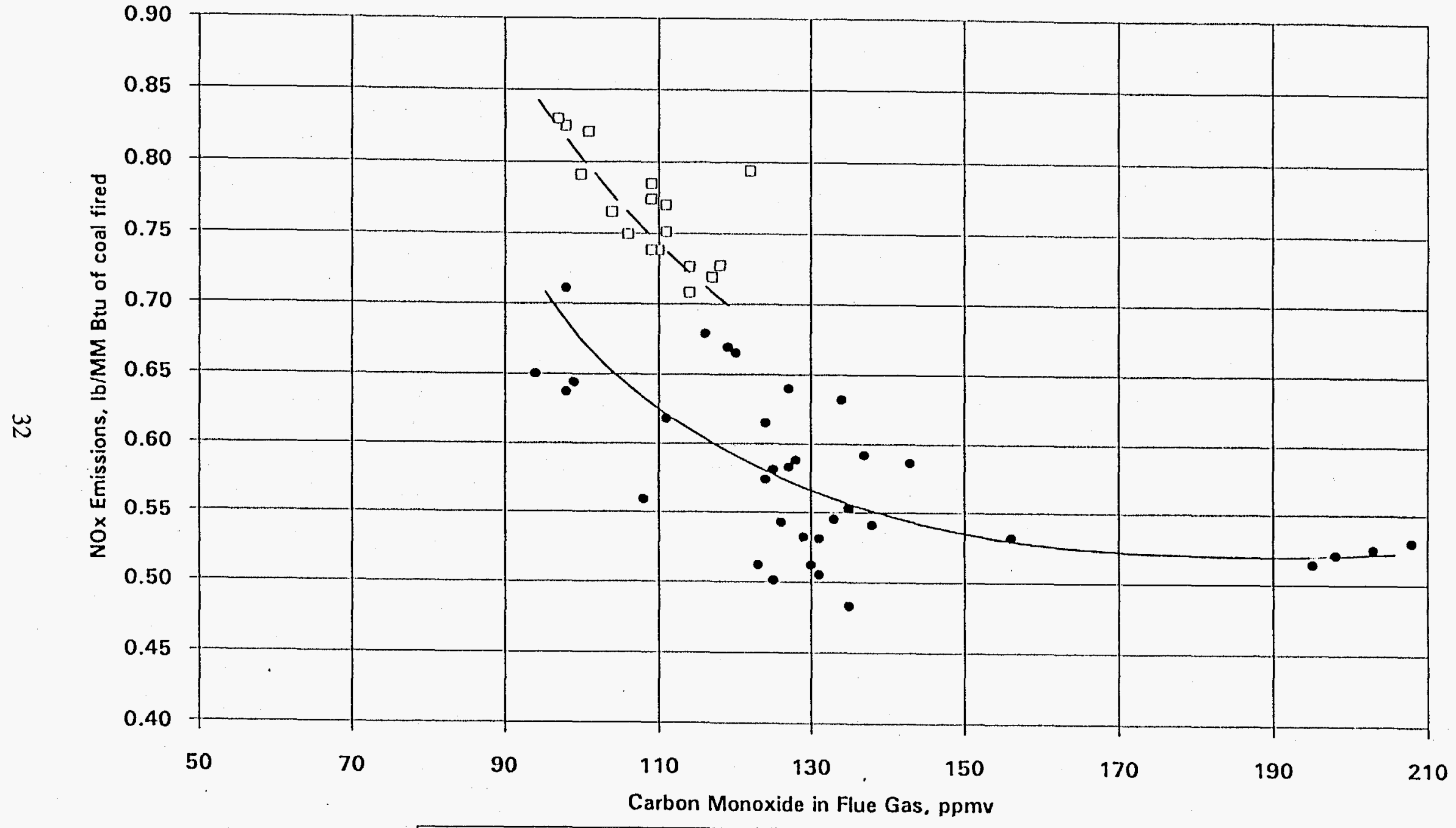

- Dolomitic limestone $\mathrm{Ca} / \mathrm{S}=2.5 \quad \square$ Dolomitic limestone $\mathrm{Ca} / \mathrm{S}=1.75$

Figure 3-6. NOx emissions versus flue gas $\mathrm{CO}$ concentration 
The somewhat lower NOx emissions for the CLF demonstration compared to the pilot unit may well be the result of the sorbent reinjection system included on the CLF system which increased the calcium loading in the fluidized bed of sand.

\subsubsection{Thermal Efficiency}

The thermal efficiency of hot water out to fuel in for the various run periods examined ranged from $43 \%$ to $75 \%$. For some of the runs there was a buildup of sorbent/flyash in the boiler which could account for the low efficiency. Also, flue gas recycle rates have not yet been optimized to yield the highest efficiencies that might be obtained.

\subsubsection{Fly Ash/Sorbent Use}

The Ohio Agricultural Research and Development Center (OARDC) evaluated the potential use of the flyash/sorbent mixture as a soil cement and also as a soil conditioner (lime substitute) for acid soils. In both applications it was determined that the flyash/sorbent mixture could have market potential. In the tests for use as a soil conditioner, it was determined that with normal application, trace elements in the ash were within acceptable limits so as not to produce any soil contamination problems. OARDC has collected a fairly large quantity of the flyash/sorbent produced for use as a soil cement to make a concrete feed lot for sheep. It is expected that the feed lot will be completed in August, 1997. 


\subsection{COMMERCIAL UNIT DESIGN}

The AFBC installed at Cedar Lane Farms is a prototype model. It was not sized to be economical for sale to the small industrial user market, but was large enough to demonstrate the technology. The next step toward commercialization is the design and testing of a larger preproduction AFBC which will be an economical size that can be competitively marketed. WillBurt determined that the pre-production AFBC system should be designed to fire approximately $10 \times 10^{6} \mathrm{Btu} / \mathrm{hr}$ of coal. The Will-Burt Company contracted with the Energy and Environmental Research Corporation (EER) to complete a design and cost estimate for a nominal $10 \times 10^{6}$ Btu/hr Atmospheric Fluidized Bed Combustion System (AFBC) to generate hot water for small scale industrial-commercial-institutional heating applications. The operational experience on the CLF AFBC was used to develop an improved design for the $10 \times 10^{6} \mathrm{Btu} / \mathrm{hr}$ AFBC.

The combustor will be square (6' $\times 6^{\prime}$ ID), rather than round, making it more amenable for Will-Burt to manufacture. A new coal distributor was designed for the AFBC that will provide uniform distribution of coal and limestone throughout the fluidized bed and preclude the possibility of sand backflow into the feed transport line. A new low pressure drop combustor startup heater was selected and incorporated into the new design. This heater will reduce both capital and electrical power costs.

The new boiler/hot water heater, unlike the CLF unit will have one downward slanted tube gas pass rather than three horizontal tube passes. It is believed that the need for soot-blowing can be eliminated with this design and that this will reduce auxiliary equipment and operating costs slightly. The heater, by having one tube pass rather than three, will diminish the tendency of ash/calcium solids to buildup in the heat exchanger tubes. Further, sorbent reinjection will occur from a hopper at the exit of the heat exchanger and more sorbent will be captured and reinjected than that for the CLF system. Therefore, there is the potential of further reducing the $\mathrm{Ca} / \mathrm{S}$ ratio required to lower $\mathrm{SO}_{2}$ emissions down to the $1.2 \mathrm{lb} /$ million Btu level.

An air blower was also selected to transport the coal/limestone into the AFBC in accord with the modification made on the CLF unit. The use of an air blower should eliminate feed pipe pluggage problems. By using air from a separate air blower, rather than flue gas from the flue gas recycle blower, electrical power consumption is also reduced; less gas needs to be delivered at the higher pressure required for coal/limestone transport. 
With the new design also, a separate air blower and separate flue gas recycle blower is used rather than the combined approach used in the CLF system. This modification will provide for better control of system oxygen that will insure maximum thermal efficiency for the unit.

This design and cost estimate study was part of the due diligence required to actively promote the commercialization of the AFBC. One objective of this work was to develop a design for a $10 \times 10^{6} \mathrm{Btu} / \mathrm{hr}$ fluid bed combustor for Will-Burt's use to accurately estimate fabrication costs. Another objective was to complete a preliminary overall system design and cost estimate for a nominal $10 \times 10^{6} \mathrm{Btu} / \mathrm{hr}$ AFBC so that Will-Burt could assess the economic potential for the AFBC in the industrial-commercial-institutional heating marketplace. As part of the study, the following were completed:

$\begin{array}{ll}\text { - } & \text { Process Design } \\ \text { - } & \text { Equipment Sizing } \\ \text { - } \quad \text { Fabrication Drawings for AFBC } \\ \text { - } \quad \text { Cost Estimatent for } 10 \times 10^{6} \mathrm{Btu} / \mathrm{hr} \text { AFBC System } \\ \text { Economics }\end{array}$

\subsection{Process Description}

Run of mine coal (2"x 0" size) is unloaded to an existing coal bin or new coal bin (provided by others). A screw conveyor transports coal from the bin to a reversible impactor crusher where the coal size is reduced to minus $1 / 2$ " (optionally to reduce the capital cost, rather than installing a coal crusher, minus $1 / 2$ " coal could be purchased). The crushed coal then drops into a coal hopper. In a like manner to coal, limestone (minus 10 mesh size) is brought to the site by dump truck and dumped into an existing bin or new limestone bin (provided by others). A screw conveyor transports limestone from the bin to a limestone hopper (see Process Flow Diagram, Figure 4-1). Both the coal and limestone hoppers are equipped with variable speed drive augers. The coal from the hopper is augured into a standpipe that feeds a rotary airlock feeder. In parallel to the coal feed, limestone is also augured into the standpipe. In the rotary feeder, coal and limestone are mixed and then fall into a coal transport eductor. The augered coal rate is set to provide the energy release required to maintain the fluid bed at the desired temperature. The limestone to coal ratio is set to yield the $\mathrm{SO}_{2}$ capture desired. The speed of the limestone auger 


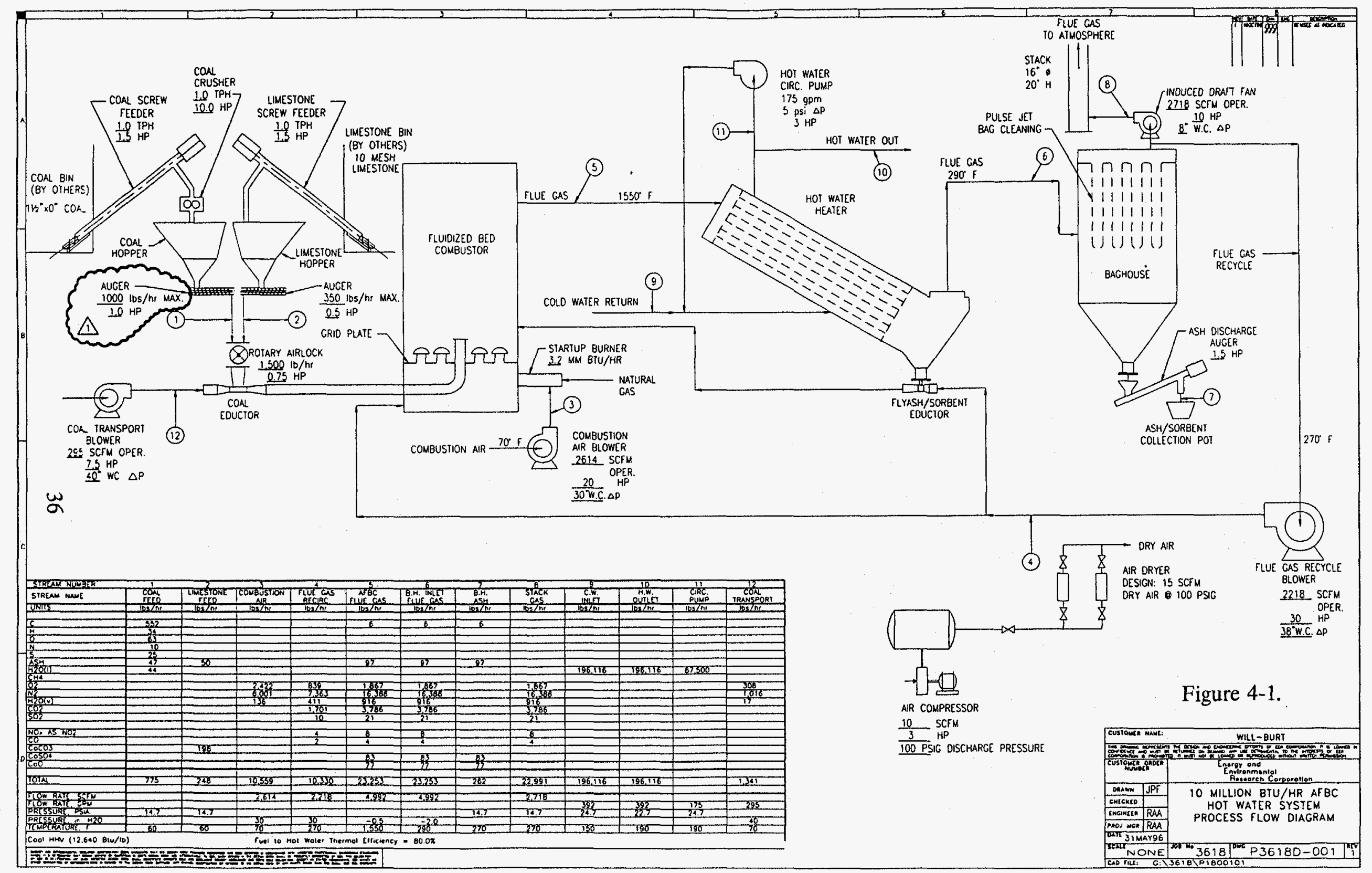


is varied with the coal feed rate to keep a desired calcium to coal sulfur molar ratio (nominally a $\mathrm{Ca} / \mathrm{S}$ ratio of 2.5). This is the ratio required to reduce sulfur dioxide emissions, when burning high sulfur Ohio coal, to $1.2 \mathrm{lb} \mathrm{SO}_{2}$ /million Btu of coal fired. The AFBC was designed to meet current and expected future air emission standards for $\mathrm{SO}_{2}$ and particulate emissions. A coal transport air blower supplies air to the coal eductor to pneumatically transport the coal and limestone into the AFBC. The transport line enters the AFBC wind box and then passes up through the center of the AFBC air distribution grid plate, into the bottom of the fluid bed. The coal and limestone enter the bed by using a four-pipe distributor, evenly feeding coal and limestone into each quadrant of the fluid bed. Graded sand (nominally 10 mesh) is used as the inert fluid bed media.

Both coal combustion and sulfur dioxide capture take place in the fluid bed. The combustion air to the AFBC is provided by a combustion air blower and a flue gas recycle blower. These two blowers are controlled independently to provide the oxygen required for combustion and the gas velocity required to fluidize the bed of sand/coal/limestone.

Coal Combustion:

$$
(\mathrm{C}, \mathrm{H}, \mathrm{O}, \mathrm{N}, \mathrm{S})+\mathrm{O}_{2}->\mathrm{CO}_{2}+\mathrm{H}_{2} \mathrm{O}+\mathrm{SO}_{2}+\mathrm{N}_{2}
$$

Sulfur Dioxide Capture:

$$
\begin{aligned}
& \mathrm{CaCO}_{3}+\text { heat }->\mathrm{CaO}+\mathrm{CO}_{2} \\
& \mathrm{CaO}+\mathrm{SO}_{2}->\mathrm{CaSO}_{3} \\
& \mathrm{CaO}+\mathrm{SO}_{2}+1 / 2 \mathrm{O}_{2}->\mathrm{CaSO}_{4}
\end{aligned}
$$

The AFBC is a square, refractory lined vessel that is $10^{\prime} 6^{\prime \prime}$ high with external and internal plan dimensions of $8^{\prime} \times 8^{\prime}$ and $6^{\prime} 4^{\prime \prime} \times 6^{\prime} 4^{\prime \prime}$ respectively. The combustor is composed of two sections, a lower insulated windbox and an upper insulated refractory lined combustion chamber. The two sections are separated by a $1 / 4$ " 310 ss grid plate that contains 72 bubble caps. The air and recycled flue gas (FGR) are distributed through the bubble caps to provide for even fluidization of the sand/coal/limestone bed. The combustor proper has no internal heat exchanger surfaces.

The hot flue gases, exiting the combustion chamber $\left(1550^{\circ} \mathrm{F}\right)$ pass through a one pass inclined waste heat exchanger to generate hot water for use in heating applications. Flue gas that is passing through the tubes heats the water that is passing through the shell of the heat exchanger. The cold recirculated water from the main water pump enters the hot water heater at $150^{\circ} \mathrm{F}$ and is heated up to $190^{\circ} \mathrm{F}$ prior to flowing to the space or process heating application. Another water pump, circulating $175 \mathrm{gpm}$ from the hot water discharge back to the cold water inlet, is 
tube/tube sheet thermal shock upon startup of the main water pump. A knockout pot is located on the heat exchanger flue gas discharge to capture unburned carbon and the larger fly ash/limestone particles. The large particles that fall into the cone bottom of the knockout pot are fed into a fly ash/sorbent eductor which educts the particles back into the fluidized bed combustion chamber using recycled flue gas as the carrier gas. This feature increases carbon utilization and limestone calcium utilization for capturing $\mathrm{SO}_{2}$.

From the heat exchanger the cooled flue gas $\left(290^{\circ} \mathrm{F}\right)$ enters a cartridge type baghouse for removal of particulate prior to entering an induced draft (ID) fan. The baghouse contains 16 Ryton cartridge type filter elements with a total area of 840 square feet. The baghouse incorporates a reverse jet pulse system that periodically blows the spent limestone sorbent and fly ash from the bags. The material drops into a hopper which feeds an ash discharge auger. The auger is started and stopped automatically to transport the fly ash and spent sorbent into an ash/sorbent collection pot (by others). From the ID fan, the clean flue gases pass up through a stack to the atmosphere.

The AFBC also incorporates a flue gas recycle (FGR) system. An FGR fan is used for flue gas recirculation; the suction line is on the inlet to the ID fan. A combustion air blower is used to provide fresh air into the fluid bed system. Recycled flue gas is blended with the fresh air prior to entering the AFBC windbox. The rate of fresh air is controlled to maintain the desired oxygen concentration in the flue gas exiting the fluid bed.

The recycled flue gas-fresh air mix that enters the windbox of the AFBC flows up through a grid plate distributor, providing combustion air to the system and also providing the proper gas velocity to fluidize the bed of sand, limestone and coal. As the flue gas recycle rate is increased, the fresh air rate is reduced and the oxygen content of the gas entering the wind box decreases. This flue gases recycle technique increases the overall thermal efficiency of the unit some $4-5 \%$ compared to air-only combustion systems. This technique also provides a means to reduce NOx emissions, at lower oxygen concentrations in the fluid bed, carbon monoxide increases and NOx decreases.

This new design will incorporate modifications that resolve the few remaining minor operational/maintenance concerns of the Cedar Lane Farms personnel; such as a better coal feed system, a new and simpler to operate gas startup heater, better access to combustor internals, new refractory design to control refractory cracking, elimination of solids buildup in the boiler proper and a better door seal on the baghouse. 


\subsection{Mass and Energy Balances}

Mass and energy balances for the $10 \times 10^{6} \mathrm{Btu} / \mathrm{hr}$ system are shown in Tables 4-1a,b,c,d. Individual balances are shown for the combustor (Table 4-1a), hot water heater (Table 4-1b), dust collector (Table 4-1c) and recycled flue gas (Table 4-1d). Based on an Ohio Bituminous coal with a gross heating value of $12,640 \mathrm{Btu} / \mathrm{lb}$ and a sulfur content of $3.28 \mathrm{wt} \%$ sulfur, 775 $\mathrm{lb} / \mathrm{hr}$ of coal $\left(\sim 9.8 \times 10^{6} \mathrm{Btu} / \mathrm{hr}\right)$ will be fed to the unit at design capacity. In addition, using a $\mathrm{Ca} / \mathrm{S}$ ratio of $2.5,248 \mathrm{lb} / \mathrm{hr}$ of limestone will be fed to the unit for capture of sulfur dioxide.

The system has an $80 \%$ overall thermal efficiency with $7.84 \times 10^{6} \mathrm{Btu} / \mathrm{hr}$ being transferred to the recirculated water for space/process heating. The flue gas recycle rate will be set to provide for approximately $8 \mathrm{vol} \% \mathrm{O}_{2}$ at the flue gas exit of the hot water heat exchanger. This oxygen percentage is based on the firing of Bituminous coal, with younger, more reactive coals the oxygen concentration may be reduced. The oxygen content is set based on consideration of carbon monoxide $(\mathrm{CO})$ emissions; as a general rule, the higher the oxygen level, the lower the $\mathrm{CO}$ emissions. The sulfur dioxide and particulate emissions will be limited to 1.2 and 0.04 $\mathrm{lb} /$ million Btu, respectively. NOx emissions are projected at 0.45 to $0.55 \mathrm{lb} / \mathrm{million} \mathrm{Btu}$.

\subsection{Piping and Instrumentation}

A piping and instrumentation diagram for the $10 \times 10^{6} \mathrm{Btu} / \mathrm{hr}$ AFBC was developed. It shows major equipment and control instrumentation and is presented in Figure 4-2. The diagram shows the instrumentation that will be required to automatically control the system. The system includes a programmable logic control (PLC) unit that will control all of the various functions required for the AFBC system operation. The system is designed to run on automatic control with minimal operator attention required. Coal and limestone will be delivered from storage bins (supplied by others) to their respective feed hopper/auger units by automatically controlling the coal and limestone screw feeders. One level switch in the coal feed hopper and one level switch in the limestone feed hopper will provide signals to automatically start and stop the screw feeders when the hoppers reach low and high level settings. The flue gas recycle rate will be controlled based on heat load demand, the higher the demand, the greater the rate. An oxygen sensor/controller will control the rate of combustion air entering the AFBC. The control of oxygen will permit the operation of the unit at maximum overall thermal efficiency. 
TABLE 4-4a. MASS AND ENERGY BALANCE

Nominal $10 \mathrm{MM}$ Btuhr Coal Fired

\{COMBUSTOR\}

\begin{tabular}{|c|c|c|c|c|c|}
\hline \multicolumn{2}{|c|}{ Basis: $60 \mathrm{~F} \& \mathrm{H} 2 \mathrm{O}(\mathrm{l})$} & TEMP. F & \multirow[t]{2}{*}{ LB.HR } & \multirow[t]{2}{*}{ BTU/LB } & \multirow[t]{2}{*}{ BTU/HR } \\
\hline \multicolumn{3}{|l|}{ INPUT: } & & & \\
\hline FEED & & 60 & & & \\
\hline 12,640 & Btu/lb actua & & & & \\
\hline Comp. & $4+\%$ & & & & \\
\hline C & 71.15 & & 552 & & \\
\hline $\mathrm{H}$ & 4.44 & & 34 & & \\
\hline 0 & 8.13 & & 63 & & \\
\hline $\mathrm{N}$ & 1.24 & & 10 & & \\
\hline$S$ & 3.28 & & 25 & & \\
\hline $\mathrm{Cl}$ & 0.00 & & 0 & & \\
\hline Ash & 6.08 & & 47 & & \\
\hline $\mathrm{H} 2 \mathrm{O}(\mathrm{l})$ & 5.68 & & 44 & & \\
\hline total & 100.00 & & $\ldots$ & & \\
\hline Subtotal & & & 775 & 0.0 & 0 \\
\hline NATURAL G & SAS (CH4) & 60 & 0 & 0.0 & 0 \\
\hline \multicolumn{6}{|c|}{23861 Btu' $1 \mathrm{~b}, \mathrm{HHV}$} \\
\hline AIR & แт\% & 70 & & & \\
\hline $\mathrm{O} 2$ & 22.94 & & 2,730 & 2.1 & 5,858 \\
\hline $\mathrm{N} 2$ & 75.77 & & 9,017 & 2.4 & 21,829 \\
\hline $\mathrm{H} 2 \mathrm{O}(\mathrm{v})$ & 1.28 & & 153 & 1064.0 & 162,578 \\
\hline$(\mathrm{MW}=$ & 28.797 & ) & (n........... & & (n)................. \\
\hline Subtotal & 2614 & $\operatorname{acfm}$ & 11,900 & & 190,264 \\
\hline F.G. REC. & vol\% & 270 & & & \\
\hline $\mathrm{O} 2$ & 7.48 & & 839 & 46.4 & 38,913 \\
\hline $\mathrm{N} 2$ & 74.98 & & $7,36 \hat{3}$ & 51.7 & 380,858 \\
\hline $\mathrm{H} 2 \mathrm{O}(\mathrm{v})$ & 6.51 & & 411 & 1153.5 & 474,561 \\
\hline $\mathrm{CO} 2$ & 11.02 & & 1,701 & 45.4 & 77,217 \\
\hline $\mathrm{SO} 2, \mathrm{ppmv}$ & 427 & & 10 & 33.0 & 316 \\
\hline $\mathrm{HCl}, \mathrm{ppm} v$ & 0 & & 0 & 42.2 & 0 \\
\hline NOx,ppmv & 223 & & 4 & 45.4 & 163 \\
\hline $\mathrm{CO}, \mathrm{ppm}$ & 181 & & 2 & 54.1 & 96 \\
\hline Ash & & & 0 & 46.3 & 6 \\
\hline Carbon & & & 0 & 33.7 & 0 \\
\hline $\mathrm{CaSO} 4$ & Gas MW $=$ & 29.464 & 0 & 42.1 & 5 \\
\hline $\mathrm{CaO}$ & 2218 & scfm & 0 & 37.9 & 4 \\
\hline Total & 100.00 & & 10,330 & & 972,139 \\
\hline & Mol. $W_{\mathrm{t}}$ & & & & \\
\hline $\mathrm{CaCO}_{3}$ & 100.09 & 60 & 198 & & \\
\hline Ash & & & 50 & & \\
\hline Subtotal & & & 248 & 0.0 & 0 \\
\hline Heat of Comb & bustion & & & & $9,722,473$ \\
\hline TOTAL & & & 23,253 & & $10,884,877$ \\
\hline
\end{tabular}

OUTPUT:

FLUE GAS

vol\%

1550

$\mathrm{O} 2 \quad 7.48$

$\mathrm{N} 2 \quad 74.98$

$\mathrm{H} 2 \mathrm{O}(\mathrm{v}) \quad 6.51$

$\mathrm{CO} 2 \quad 11.02$

SO2,ppmv $\quad 427$

$\mathrm{HCl}$,ppmv $\quad 0$

NOx,ppmv $\quad 223$

CO,ppmv $\quad 181$

A.sh $\quad$ sfgv $=$

Carbon $\quad 8.0 \mathrm{fps}$

$\mathrm{CaSO} 4$

$61 / 3^{\prime} \times 61 / 3^{\prime} 1$.

$\mathrm{CaO} \quad \mathrm{Gas} \mathrm{MW}=$

$4992 \mathrm{scfm}$

100.00

$5.00 \%$

29.464

1,867

1,867
16,388

363.7

392.5

1806.5

392.7

276.6

274.1

392.7

399.1

327.8

238.4

298.0

Subtotal

23,253

268.2

$\begin{array}{r}679,053 \\ 6,431,731 \\ 1,654,105 \\ 1,486,687 \\ 5,907 \\ 0 \\ 3,145 \\ 1,579 \\ 31,739 \\ 1,317 \\ 24,719 \\ 20,652 \\ \hline 10,340,633 \\ 544,244 \\ \hline 10,884,877\end{array}$

TOTAL

23,253

$100.00 \%$ 
TABLE 4-4b. MASS AND ENERGY BALANCE

Nominal $10 \mathrm{MM}$ Btu/hr Coal Fired

\{HOT WATER HEATER\}

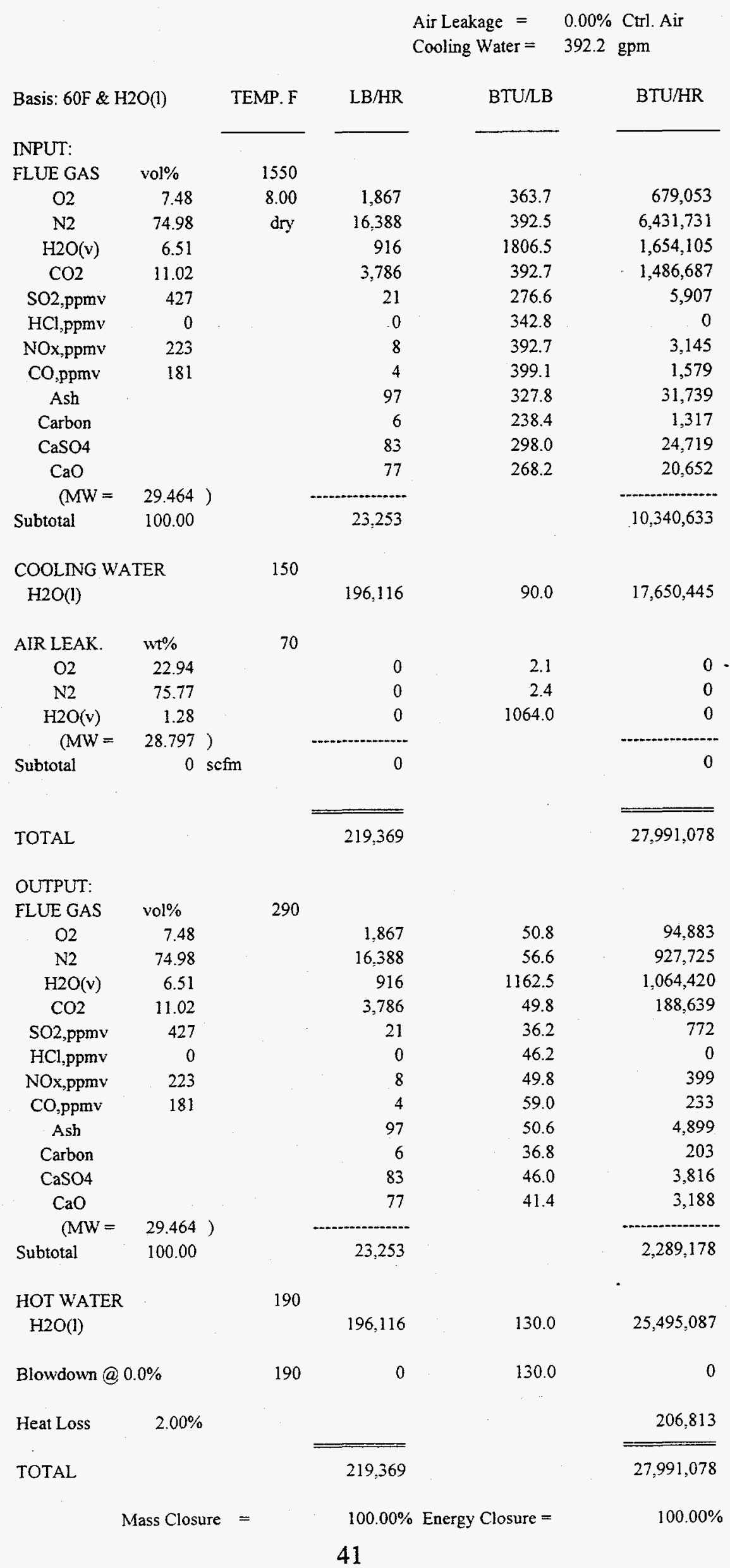


Nominal $10 \mathrm{MM}$ Btu/hr Coal Fired

\{BAG HOUSE\}

EFFICIENCY $=$

TEMP.F

$\mathrm{LB} / \mathrm{HR}$

Basis: $60 \mathrm{~F} \& \mathrm{H} 2 \mathrm{O}(1)$

NPUT:

FLUE GAS

$\mathrm{O} 2$

N2

vol\%

$\mathrm{H} 2 \mathrm{O}(\mathrm{v})$

$\mathrm{CO} 2$

$\mathrm{SO} 2, \mathrm{ppmv}$

$\mathrm{HCl}$,ppmv

NOx,ppmv

$\mathrm{CO}$,ppmv

Ash

Carbon

$\mathrm{CaSO} 4$

$\mathrm{CaO}$

$(\mathrm{MW}=29.464)$

TOTAL

100.00

OUTPUT:

FLUE GAS

$\mathrm{O} 2$

$\mathrm{N} 2$

$\mathrm{H} 2 \mathrm{O}$ (v)

$\mathrm{CO} 2$

$\mathrm{SO} 2, \mathrm{ppmv}$

$\mathrm{HCl}$,ppmv

NOx,ppmv

$\mathrm{CO}, \mathrm{ppmv}$

Ash

Carbon

$\mathrm{CaSO} 4$

$\mathrm{CaO}$

(MW =

Subtotal

29.464 )

B.H. SOLIDS

Ash

Carbon

$\mathrm{CaSO} 4$

$\mathrm{CaO}$

Subtotal

Heat Loss

$5.00 \%$

TOTAL
100.00

vol\%

7.48

74.98

6.51

11.02

427

0

223

181$$
100.00
$$

290

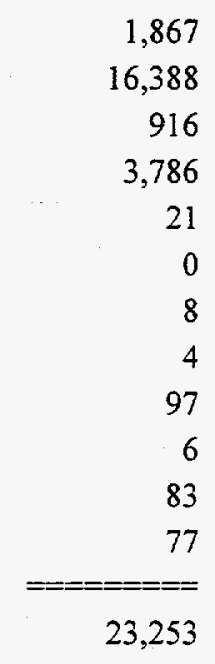

270

$8.00 \%$
dry

1,867

dry $\quad 16,388$

916

3,786

21

0

8

4

0

0

0

0

22,991

270

$\begin{array}{r}97 \\ 6 \\ 83 \\ 77 \\ \hline 262\end{array}$

46.3

33.7

42.1

37.9

50.8

56.6

1162.5

49.8

36.2

46.2

49.8

59.0

50.6

36.8

46.0

41.4

46.4

51.7

1153.5

45.4

33.0

42.2

45.4

54.1

46.3

33.7

42.1

37.9

86,609

847,669

$1,056,223$

171,861

704

0

364

214

13

1

10

8

$2,163,675$

262

4,469

185

3,481

2,908

11,044

114,459

$=====$

$2,289,178$

$100.00 \%$ 
TABLE 4-4d. MASS AND ENERGY BALANCE

Nominal $10 \mathrm{MM}$ Btuhr Coal Fired

\{FLUE GAS RECYCLE\}

Flue Gas Recycle @ $\quad 44.93 \%$

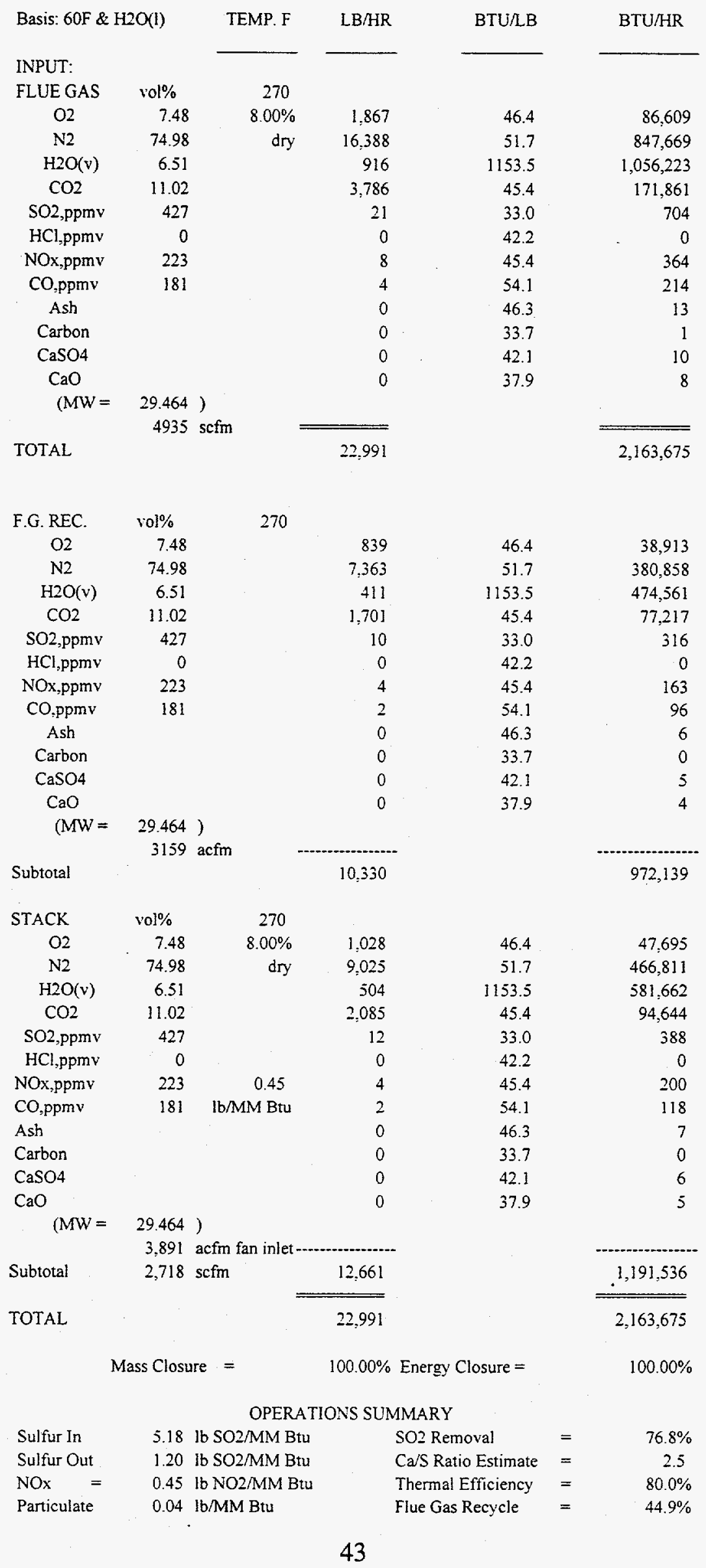




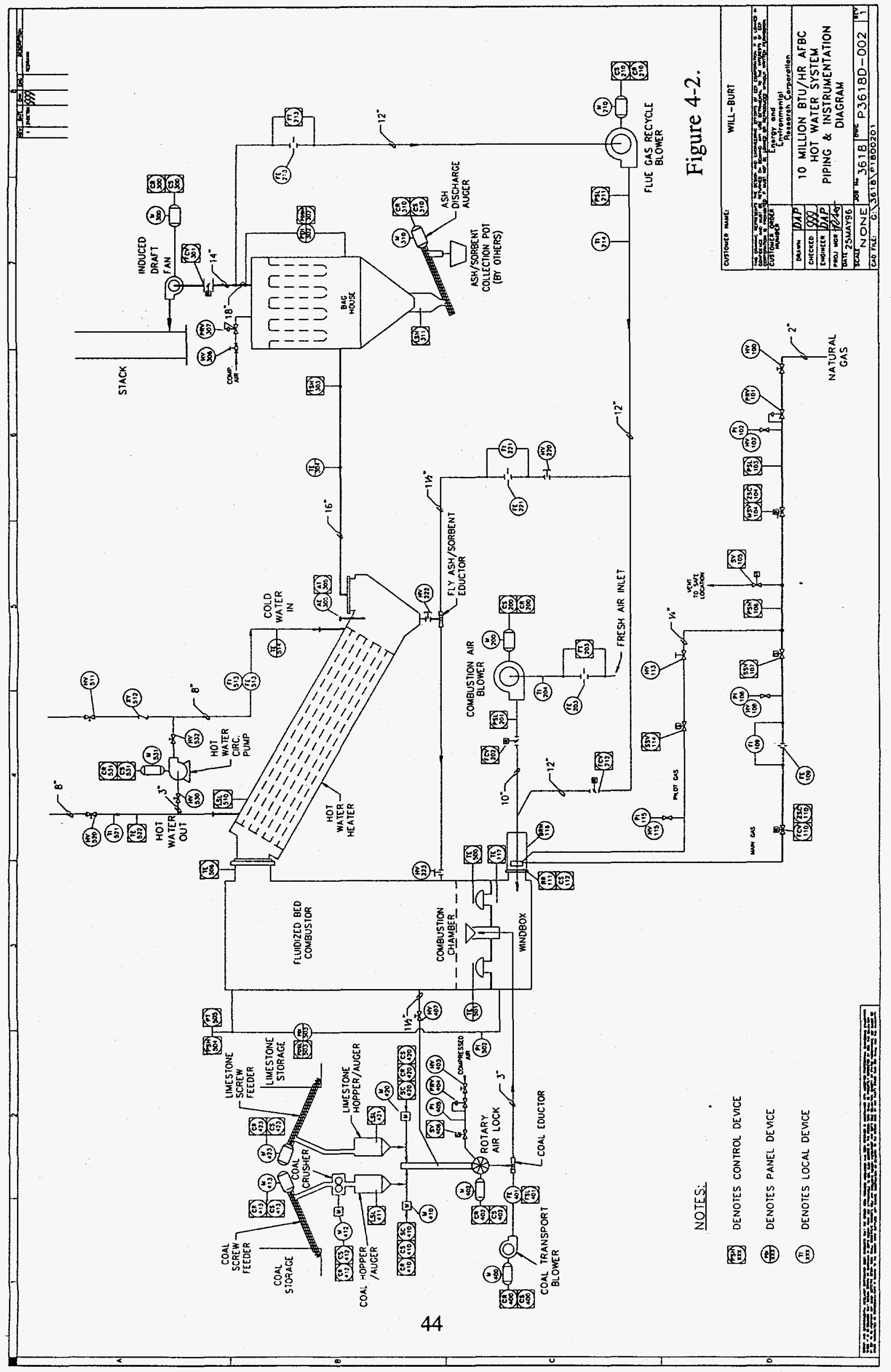


The coal feed rate will be controlled to maintain the desired temperature in the fluid bed combustor. The limestone rate will be ratio controlled to the coal feed rate to provide the desired $\mathrm{Ca} / \mathrm{S}$ ratio in the fluid bed. The coal transport and flyash/sorbent eductors will be run with constant supply rates of carrier gas. The pressure in the fluid bed combustor will be controlled by a damper on the inlet to the ID fan to maintain about -0.2 inches W.C. above the sand bed.

The dust collector is equipped with a reverse air jet cleaning system that will be automatically activated at specified time intervals to ensure that the cartridge filters are kept clean. Dirty cartridge filters translate to higher pressure drops which then translate to greater horsepower requirements for the induced draft fan. The baghouse ash discharge auger will be automatically started up and shut down based on the solids level in the baghouse hopper. The auger will discharge into an ash/sorbent collection pot (provided by others).

\subsection{Equipment List}

A major equipment list was developed for the $10 \times 10^{6} \mathrm{Btu} / \mathrm{hr}$ unit that included the sizing and a description of equipment features. Quotations were obtained from vendors on all major equipment items, and in most cases at least two quotations were received. A simplified equipment list is presented below. Besides the equipment previously described, included is a natural gas startup burner and a small air compressor that includes a dryer.

\section{MILLION BTU/HR AFBC MAJOR EQUIPMENT LIST}

\section{Coal Screw Feeder}

Service

Type

Capacity

\section{Coal Crusher (optional)}

Service

Type

Capacity

Coal Hopper/Auger

Service

Type

Capacity
Delivery of coal to crusher

Will-Burt Model \# HL2BF

$2000 \mathrm{lb} / \mathrm{hr}$

Crushing of delivered coal

Pennsylvania Crusher Reversible Impactor

$2000 \mathrm{lb} / \mathrm{hr}$

Surge tank and metering of coal to AFBC

Will-Burt Model \#75F

$775 \mathrm{lb} / \mathrm{hr}$ (normal oper.) 1,000 lb/hr (max.) 
Limestone Screw Feeder

Service

Type

Capacity

\section{Limestone Hopper/Auger}

Service

Type

Capacity

Rotary Airlock

Service

Type

Capacity

\section{Coal Eductor}

Service

Type

Capacity

Coal Transport Blower

Service

Type

Rated Capacity

Fluidized Bed Combustor

Service

Type

Duty

Combustion Air Blower

Service

Type

Rated Capacity

Flue Gas Recycle (FGR) Blower

Service

Type

Rated Capacity
Delivery of limestone to limestone feeder

Will-Burt Model \# HL2BF

$2000 \mathrm{lb} / \mathrm{hr}$

Surge tank and metering of limestone to AFBC Will-Burt Model \# 30F

$250 \mathrm{lb} / \mathrm{hr}$ (normal oper.) $350 \mathrm{lb} / \mathrm{hr}$ (max.)

Coal + limestone airlock for pneumatic conveyor W.M. Meyer Roto-Flo rotary valve $1500 \mathrm{lb} / \mathrm{hr}$

Coal/limestone transport to AFBC

Will-Burt

$1100 \mathrm{lb} / \mathrm{hr}$

Coal and limestone pneumatic transport

Cincinnati Fan

$275 \mathrm{acfm}$

Coal combustion and capture of sulfur dioxide Will-Burt Model \# AFBC - 10, refractory lined Nominally $-10 \times 10^{6} \mathrm{Btu} / \mathrm{hr}$

Supply of combustion air to AFBC Cincinnati Fan

$2668 \mathrm{acfm}$

Recirculation of flue gas from baghouse to AFBC Cincinnati Fan

$3475 \mathrm{acfm}$ 
Hot Water (HW) Heater

Service

Type

Heat Recovery

HW Circulation Pump

Service

Type

Rated Capacity

Fly Ash/Sorbent Eductor

Service

Type

Capacity

Dust Collector

Service

Type

Capacity

Induced Draft (ID) Fan

Service

Type

Rated Capacity

Ash Discharge Auger

Service

Type

Capacity

$\underline{\text { Stack }}$

Service

Type

Startup Burner

Service

Type

Air Compressor

Service

Type

Pressure
Hot water production

EnerCorp Inc. single pass heat recovery unit $9.7 \times 10^{6} \mathrm{Btu} / \mathrm{hr}$

Circulation of water through heater MEPCO

$175 \mathrm{gpm}$

Recirculation of ash/sorbent, from heater to AFBC Will-Burt

$1000 \mathrm{lb} / \mathrm{hr}$

Cartridge dust collector

Aerotech cartridge filter $w /$ reverse jet cleaning

5,603 acfm (design), 4,935 acfm (normal oper.)

Induced draft to maintain neg. pressure on AFBC Cincinnati Fan

$4259 \mathrm{acfm}$

Ash/sorbent discharge conveyor

Will-Burt Model \# HL2BF

$2000 \mathrm{lb} / \mathrm{hr}$

Discharge of flue gas to atmosphere

$16^{\prime \prime}$ sch. 40 pipe, $20^{\prime}$ high w/bottom anchor plate

Combustion air heating during startup

Eclipse

Air for baghouse cleaning and rotary air lock purge Two stage reciprocating $w / 80$ gallon receiver 100 psig (normal discharge) 175 psig (max.) 


\section{Air Dryer}

Type

Capacity

Pressure Rating
Regenerative desiccant

15 scfm of dry air @ 100 psig

150 psig (max.)

\subsection{Equipment Layout and Elevations}

Preliminary equipment layout and elevation drawings were completed based on the developed design. The equipment layout and elevations are shown in Figure 4-3.

\subsection{Cost Estimate}

The direct costs for construction were developed for the $10 \times 10^{6} \mathrm{Btu} / \mathrm{hr}$ AFBC system, and all costs are shown are in 1996 dollars. The cost estimate presented summarizes material fabrication, instrumentation, equipment and installation costs. The estimate does not include freight, taxes, profit, General and Administration (G\&A), overhead, contingency, home office support, engineering or start-up. Will-Burt can use these direct construction costs to develop total installed cost based on values for those items not included that are specific to Will-Burt's pricing factors.

\subsubsection{Basis of Construction Cost Estimate}

The estimate has been developed using three sources of information for equipment pricing and labor costs. These sources are as follows:

- Vendor Quotations for Major Equipment

- Questimate Cost Estimating Software by Icarus Corp.

- $\quad$ EER's database of previous equipment purchases

The following assumptions were made for completing the estimate:

1. Monetary Currency: 1996 U.S. dollars.

2. System will be constructed within existing building.

3. Ducts will be shop fabricated and shipped in sections.

4. $40 \mathrm{hr}$ work week - no overtime

5. No spare parts included. 


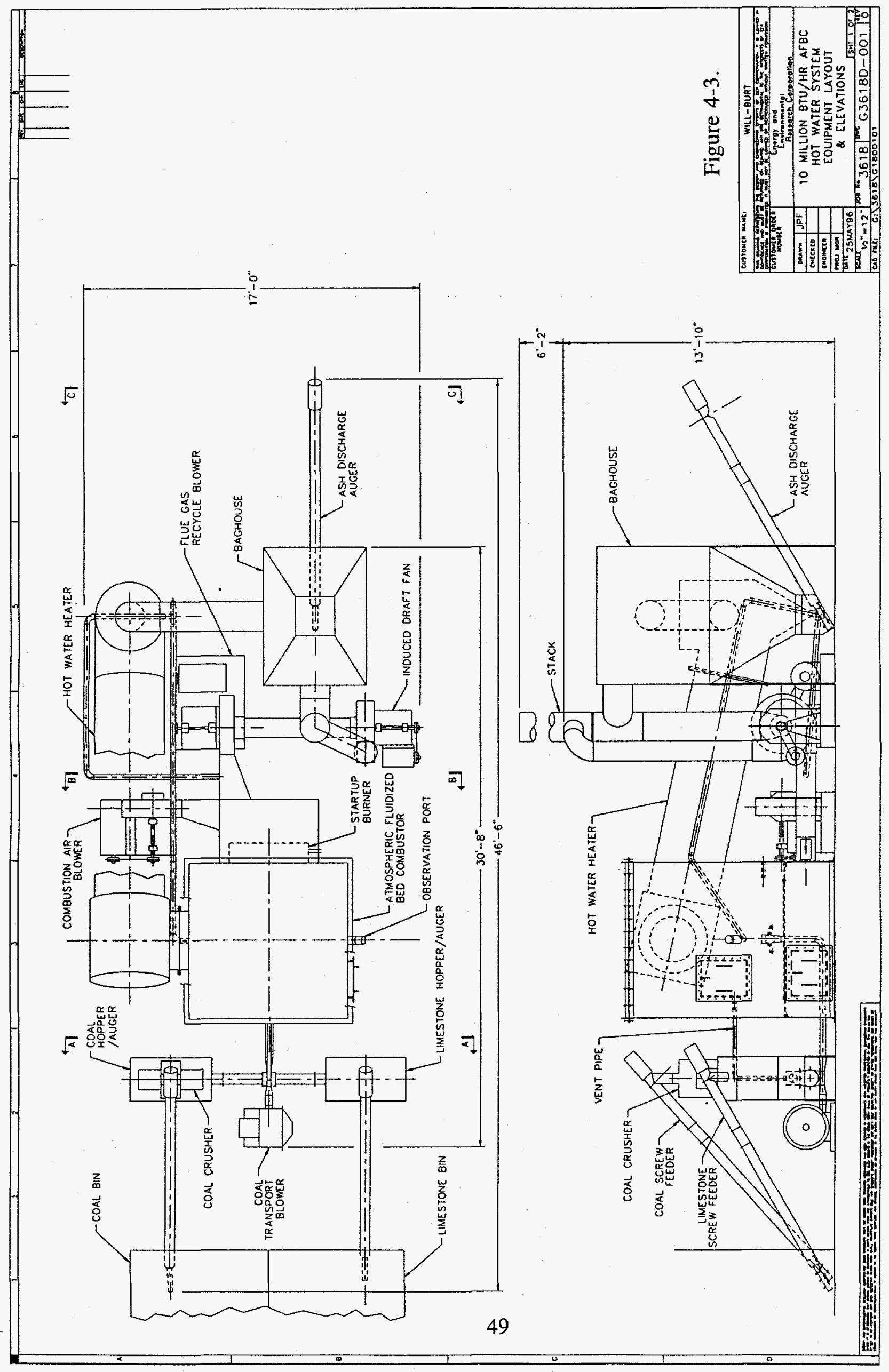


7. The base construction labor rate w/o supervision of $\$ 40 / \mathrm{manhr}$

8. Coal and limestone storage bins and the ash/sorbent collection pot are existing or will be provided by others

A list of major equipment costs, approximate bulk material takeoffs, and installation labor and supervision were compiled to arrive at direct construction costs. In most cases, quotations from two vendors were obtained on all major equipment items. EER considers these costs to be representative of the actual cost within an accuracy of $-10 \% /+15 \%$. This estimate is based on a preliminary process design, basic engineering, major equipment quotes, bulk material takeoff's and average expected labor rates and productivity.

\subsubsection{Direct Construction Cost Summary}

The total direct construction cost for a $10 \times 10^{6} \mathrm{Btu} / \mathrm{hr}$ AFBC system is estimated at $\$ 333,361$, $\$ 224,361$ being required for equipment and $\$ 89,000$ for construction labor. The estimate does not include supervision, freight, taxes, profit, $G \& A$, overhead, engineering, home office support, contingency or start-up.

\subsubsection{Vendor Quotes}

EER received quotes on all of the fans, feed hoppers, coal crusher, rotary airlock, screws, eductors, hot water heater, and baghouse. The cost of the combustor proper was factored based on the cost of the AFBC installed at Cedar Lane Farms.

\subsection{Economics}

Capital and operating costs for the $10 \times 10^{6} \mathrm{Btu} / \mathrm{hr}$ AFBC were developed and a comparison was made to the capital and operating costs for a $10 \times 10^{6} \mathrm{Btu} / \mathrm{hr}$ natural gas fired hot water system. EER added its standard values for those items not included in the direct construction costs to develop a total installed cost. This total installed cost was then used to compare the economics of a coal-fired AFBC hot water system with a natural gas-fired hot water system. 


\subsubsection{AFBC Capital Cost}

The direct construction costs were used as a basis to develop the total installed cost, which includes both direct and indirect construction costs, for the AFBC hot water system. The indirect construction costs added to the direct costs shown included freight, taxes, construction indirects (including supervision @ 20\% of direct labor), depreciable capital (owners and engineering costs), and startup costs. In addition, a project contingency of $10 \%$ was added to the installed cost. Engineering costs were set based on one-fifth of the total engineering cost for the first unit designed, assuming the cost would be spread over the first five units installed. The total installed cost is estimated at $\mathbf{\$ 5 6 8 , 0 0 0}$; the cost breakdown is shown in Table $\mathbf{4 - 2}$.

\subsubsection{AFBC Operating Cost}

Operating costs were developed for the operation of the AFBC system to produce hot water. Two sets of annual operating costs were developed, one was based on a 300 day/year operation at $100 \%$ of the AFBC capacity, or a capacity factor of approximately $82 \%$, and the other one was based on a 250 day/year operation at $100 \%$ of the AFBC capacity, or a capacity factor of approximately $68 \%$. A fixed charge rate of $10 \%$ of the total installed cost was assessed to pay off the capital for the AFBC system.

The operating cost for the 300 day/year operation case is presented in Table 4-3. The cost to operate the AFBC is estimated at $\$ 232,180 /$ year, or a cost to produce hot water of $\$ 4.11 /$ Million Btu. Based on 300 days of operation at full load the cost of $\mathrm{SO}_{2}$ removal, reducing emissions from $5.185 \mathrm{lb} / 10^{6} \mathrm{Btu}$ down to $1.2 \mathrm{lb} / 10^{6} \mathrm{Btu}$ is approximately $\$ 1650 /$ ton. The operating cost for the 250 day/year operation is presented in Table 4-4. The cost to operate the AFBC at the lower capacity factor, is estimated at $\$ 208,668 / \mathrm{yr}$, or a cost to produce hot water of $\$ 4.44 /$ Million Btu. Based on 250 days of operation at full load the cost of $\mathrm{SO}_{2}$ removal, reducing emissions from $5.185 \mathrm{lb} / 10^{6} \mathrm{Btu}$ down to $1.2 \mathrm{lb} / 10^{6}$ Btu is approximately $\$ 1780 /$ ton.

\subsubsection{Comparison of AFBC with Natural Gas Fired System}

Capital and operating costs were developed for a new gas fired hot water heater to compare the cost of producing hot water using a natural gas fired heater with that for producing hot water with the AFBC system. The capital cost for an identical size hot water heater as that used for 
TABLE 4-2. 10 Million Btu/hr AFBC Total Installed Cost

Questimate

Equipment / Materials and labor

Materials Labor Hrs

$\$ 244,361$

2,225

$\frac{\text { Labor } \$}{\$ 89,000}$

Total

Facilities and Utility Systems

Subtotal: Plant Dlrect Cost

$\$ 333,361$

$\frac{\$ 0}{\$ 333,400}$

\section{Other DIrect Costs}

Site Development

Freight $(4 \%)$

Taxes (6\%)

Subtotal: Total Direct Costs

Construction Indirects

Indirect Field Personnel (15\%)

$\$ 13,350$

Contractor Overhead \& Fee $(20 \%)$

$\$ 72,640$

Other

Subtotal: Construction Cost

$\$ 449,200$

Depreciable Capital

EER Supply - Engineering, Training, PM, Procurement, Fee *

$\$ 20,000$

Owners Cost $(5 \%)$

Subtotal:

$\$ 22,460$

$\$ 491,700$

Project Contingency (10\%)

$\$ 49,170$

Process Contingency (0\%)

Subtotal: Depreciable Capital

$\$ 540,900$

Fixed Capital

Land Purchase

Other Fixed Capital

Subtotal: Fixed Capital

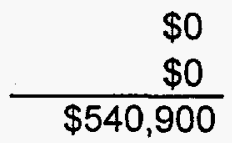

Other

Working Capital Cost

Start-up Cost (5\%)

$\$ 27,045$

Other Related Investment Expenses

Total Investment Cost

$\$ 568,000$

* Engineering cost spread over 5, identical 10MMBtu/hr AFBC's 
TABLE 4-3. AFBC for Hot Water Heating Application

9.80 Million Btu/hr of Coal Fired

7.84 Million Btu/hr of Hot Water

\section{Projected Operating Costs}

[ 300 days per year of operation @ 100\% capacity ]

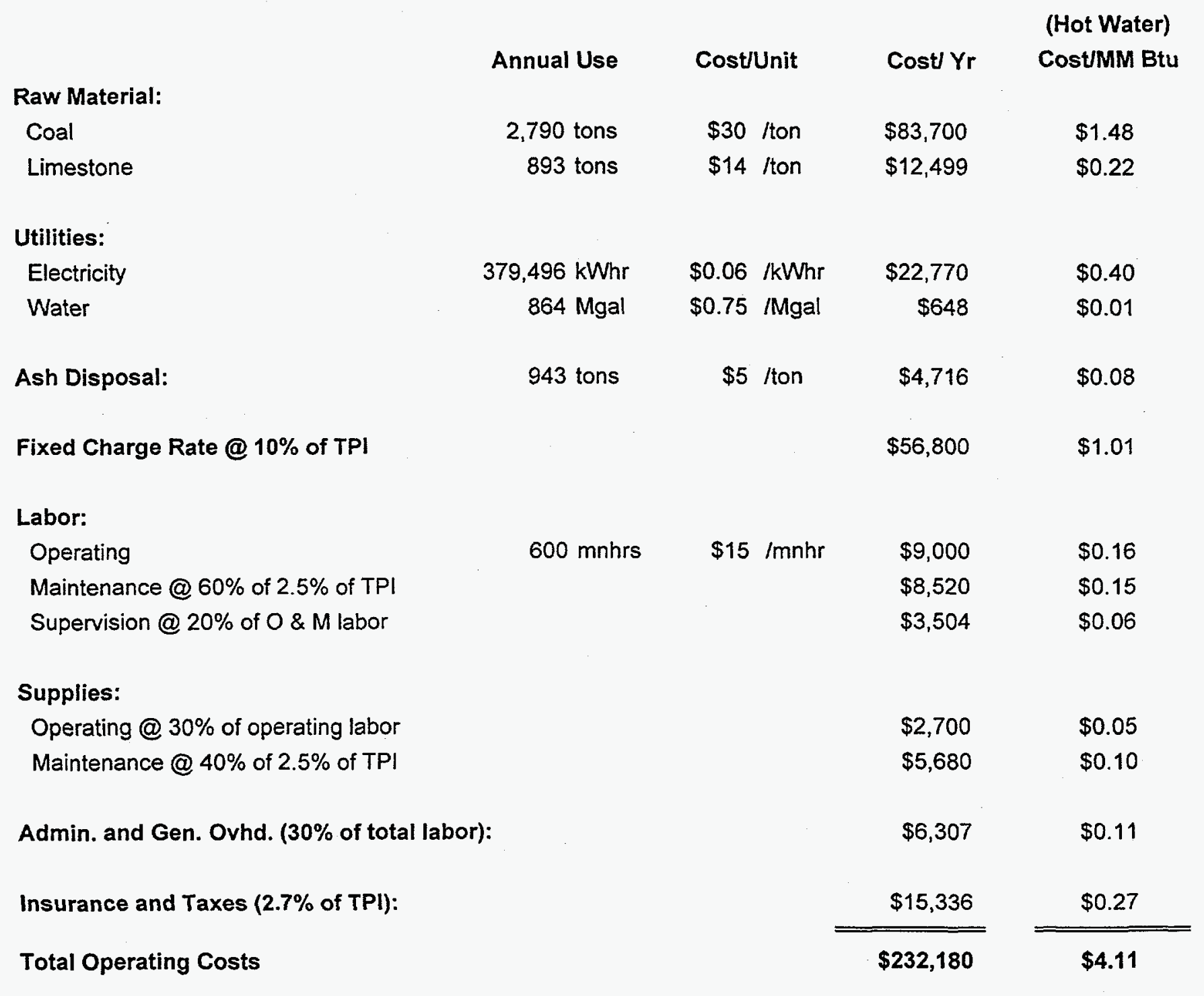




\section{TABLE 4-4. AFBC for Hot Water Heating Application \\ 9.80 Million Btu/hr of Coal Fired \\ 7.84 Million Btu/hr of Hot Water \\ Projected Operating Costs \\ [ 250 days per year of operation @ 100\% capacity ]}

Raw Material:

Coal

Limestone

Utilities:

Electricity

Water

Ash Disposal:

Fixed Charge Rate @ 10\% of TPI

Labor:

Operating

Maintenance @ $60 \%$ of $2.5 \%$ of TPI

Supervision @ $20 \%$ of O \& M labor

\section{Supplies:}

Operating @ $30 \%$ of operating labor Maintenance @ $40 \%$ of $2.5 \%$ of TPI

Admin. and Gen. Ovhd. ( $30 \%$ of total labor):

Insurance and Taxes $(2.7 \%$ of TPI):

Total Operating Costs
Annual Use

2,325 tons

744 tons

$316,247 \mathrm{kWhr}$

$720 \mathrm{Mgal}$

786 tons

500 mnhrs

$\$ 15 / \mathrm{mnhr}$

$\$ 7,500$

$\$ 8,520$

$\$ 3,204$

$\$ 2,250$

$\$ 5,680$

$\$ 5,767$

$\$ 15,336$

$\$ 208,668$
(Hot Water)

Cost/MM Btu

$\$ 1.48$

$\$ 0.22$

$\$ 0.40$

$\$ 0.01$

$\$ 0.08$

$\$ 1.21$

$\$ 0.16$

$\$ 0.18$

$\$ 0.07$

$\$ 0.05$

$\$ 0.12$

$\$ 0.12$

$\$ 0.33$

$\$ 4.44$ 
the AFBC system $\left(7.84 \times 10^{6} \mathrm{Btu} / \mathrm{hr}\right.$ of hot water produced with $9.8 \times 10^{6} \mathrm{Btu} / \mathrm{hr}$ of fuel consumed) was developed for the natural gas system. The total installed cost was estimated at $\mathbf{\$ 8 2 , 4 3 3}$ (see Table $4-5$ ). This compares to the $\mathbf{\$ 5 6 8 , 0 0 0}$ required for the AFBC system.

Two sets of annual operating costs were then developed for the natural gas case for comparison with the AFBC, one based on a 300 day/year operation at $100 \%$ capacity, and the other one based on a 250 day/year operation at $100 \%$ capacity. In 1996, Cedar Lane Farms paid $\$ 4.50 / 10^{6} \mathrm{Btu}$ of natural gas so this was the price used in the analysis. A fixed charge rate of $10 \%$ of the total installed cost was assessed to pay off the capital for the gas hot water heater. The operating cost for the 300 day/year operation case is presented in Table 4-6. The cost to operate the natural gas fired system is estimated at $\$ 341,142 /$ year or a cost for hot water of $\$ 6.04 /$ Million Btu. The operating cost for the 250 day/year operation case is presented in Table 4-7. The cost for the natural gas fired system at the lower capacity factor, is estimated at $\$ 286,397 /$ year, or a cost for hot water of $\$ 6.09 /$ Million Btu.

Based on coal being purchased at $\$ 30 /$ ton $(\$ 1.18 /$ million Btu) and natural gas at $\$ 4.50$, whereas the capital cost for the AFBC system is some $2 \frac{1 / 2}{2}$ times that of the natural gas fired system, because of the lower fuel cost, the AFBC will produce hot water at $\$ 1.65 /$ million Btu less than that for natural gas for a 250 day/year operation and $\$ 1.93 /$ million Btu less for a 300 day/year operation. When evaluating the economics for a specific AFBC system application, two factors are very important, the price differential between coal and gas or oil, and the onstream capacity factor for the heating system. The AFBC system will be more economically competitive with higher price differentials and higher capacity factors.

A cost comparison based on 250 day per year operation case for natural gas and the coal-fired AFBC was made based on varying natural gas cost. In Figure 4-4, the comparison is shown. It can be seen that when using a purchased coal price of $\$ 1.18 / 10^{6}$ Btu that the AFBC unit is competitive with natural gas when the cost of natural gas is $\$ 3.18 / 10^{6}$ Btu or greater. The average cost of natural gas to the industrial and commercial market sectors in February of 1997 was $\$ 4.21$ and $\$ 5.98 / 10^{6} \mathrm{Btu}$, respectively. Based on natural gas prices, the AFBC unit at the $10 \times 10^{6} \mathrm{Btu} / \mathrm{hr}$ size is the economical choice for new heating systems. 
TABLE 4-5. Natural Gas Fired Boiler for Hot Water Heating Application

9.80 Million Btu/hr of Natural Gas

7.84 Million Btu/hr of Hot Water

\section{Total Plant Investment}

Equipment Materials

$\$ 40,475$

Direct Construction Labor

$\$ 18,750$

Other Direct Costs (Freight @ 4\% \& Taxes @ 6\% of Materials)

$\$ 4,048$

Construction Indirects (Personnel @ 15\% and OVHD \& Fee @ 20\% of Const. Labor)

$\$ 6,563$

Depreciable Capital (Engineering @ $\$ 3,000$ and Owners Cost @ 5\% of Const. Cost)

$\$ 6,492$

Subtotal - Plant Cost

$\$ 76,327$

Startup @ 3\%

$\$ 2,290$

Subtotal

$\$ 78,617$

Project Contingency @ 5\% of Plant Cost

$\$ 3,816$

Total Plant Investment (TPI)

$\$ 82,433$ 
TABLE 4-6. Natural Gas Fired Boiler for Hot Water Heating Application

9.80 Million Btu/hr of Natural Gas

7.84 Million Btu/hr of Hot Water

Projected Operating Costs

[ 300 days per year of operation @ 100\% capacity ]

Raw Material:

Annual Use Cost/Unit Cost/Yr Cost/MM Btu

Natural Gas

70,560 MM Btu $\$ 4.50$ MM Btu $\$ 317,520$

$\$ 5.63$

Utilities:

Electricity

Water

$32,214 \mathrm{kWhr}$

$\$ 0.06 / \mathrm{kWhr}$

$864 \mathrm{Mgal}$

$\$ 0.75 \mathrm{Mgal}$

$\$ 1,933$

$\$ 0.03$

$\$ 648$

$\$ 0.01$

Fixed Charge Rate @ 10\% of TPI

$\$ 8,243$

$\$ 0.15$

Labor:

Operating 300 mnhrs

$\$ 15 / \mathrm{mnhr}$

Maintenance @ $60 \%$ of $2 \%$ of TPI

$\$ 4,500$

$\$ 989$

$\$ 0.08$

Supervision @ 20\% of O \& M labor

$\$ 1,098$

$\$ 0.02$

$\$ 0.02$

\section{Supplies:}

Operating @ $30 \%$ of operating labor

Maintenance @ $40 \%$ of $2 \%$ of TPI

Admin. and Gen. Ovhd. ( $30 \%$ of total labor):

Insurance and Taxes (2.7\% of TPI):

Total Operating Costs

\begin{tabular}{|c|c|}
\hline$\$ 1,350$ & $\$ 0.02$ \\
\hline$\$ 659$ & $\$ 0.01$ \\
\hline$\$ 1,976$ & $\$ 0.04$ \\
\hline$\$ 2,226$ & $\$ 0.04$ \\
\hline 11,14 & $\$ 6.04$ \\
\hline
\end{tabular}


TABLE 4-7. Natural Gas Fired Boiler for Hot Water Heating Application

\subsection{Million Btu/hr of Natural Gas}

\subsection{Million Btu/hr of Hot Water}

\section{Projected Operating Costs}

[ 250 days per year of operation @ 100\% capacity ]

(Hot Water)

Annual Use Cost/Unit Cost/Yr Cost/MM Btu

Raw Material:

Natural Gas

58,800 MM Btu $\quad \$ 4.50$ /MM Btu $\$ 264,600$

$\$ 5.63$

Utilities:

Electricity

$26,845 \mathrm{kWhr}$

\$0.06 $/ \mathrm{kWhr}$

$\$ 1,611$

$\$ 0.03$

Water

$720 \mathrm{Mgal}$

$\$ 0.75$ Mgal

$\$ 540$

$\$ 0.01$

Fixed Charge Rate @ 10\% of TPI

$\$ 8,243$

$\$ 0.18$

Labor:

Operating

250 mnhrs

$\$ 15 / \mathrm{mnhr}$

$\$ 3,750$

$\$ 0.08$

Maintenance @ 60\% of $2 \%$ of TPI

$\$ 989$

$\$ 0.02$

Supervision @20\% of O \& M labor

$\$ 948$

$\$ 0.02$

Supplies:

Operating @ 30\% of operating labor

$\$ 1,125$

$\$ 0.02$

Maintenance @ $40 \%$ of $2 \%$ of TPI

$\$ 659$

$\$ 0.01$

Admin. and Gen. Ovhd. (30\% of total labor):

$\$ 1,706$

$\$ 0.04$

Insurance and Taxes $(2.7 \%$ of TPI):

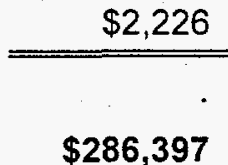

$\$ 0.05$

Total Operating Costs

$\$ 286,397$

$\$ 6.09$ 


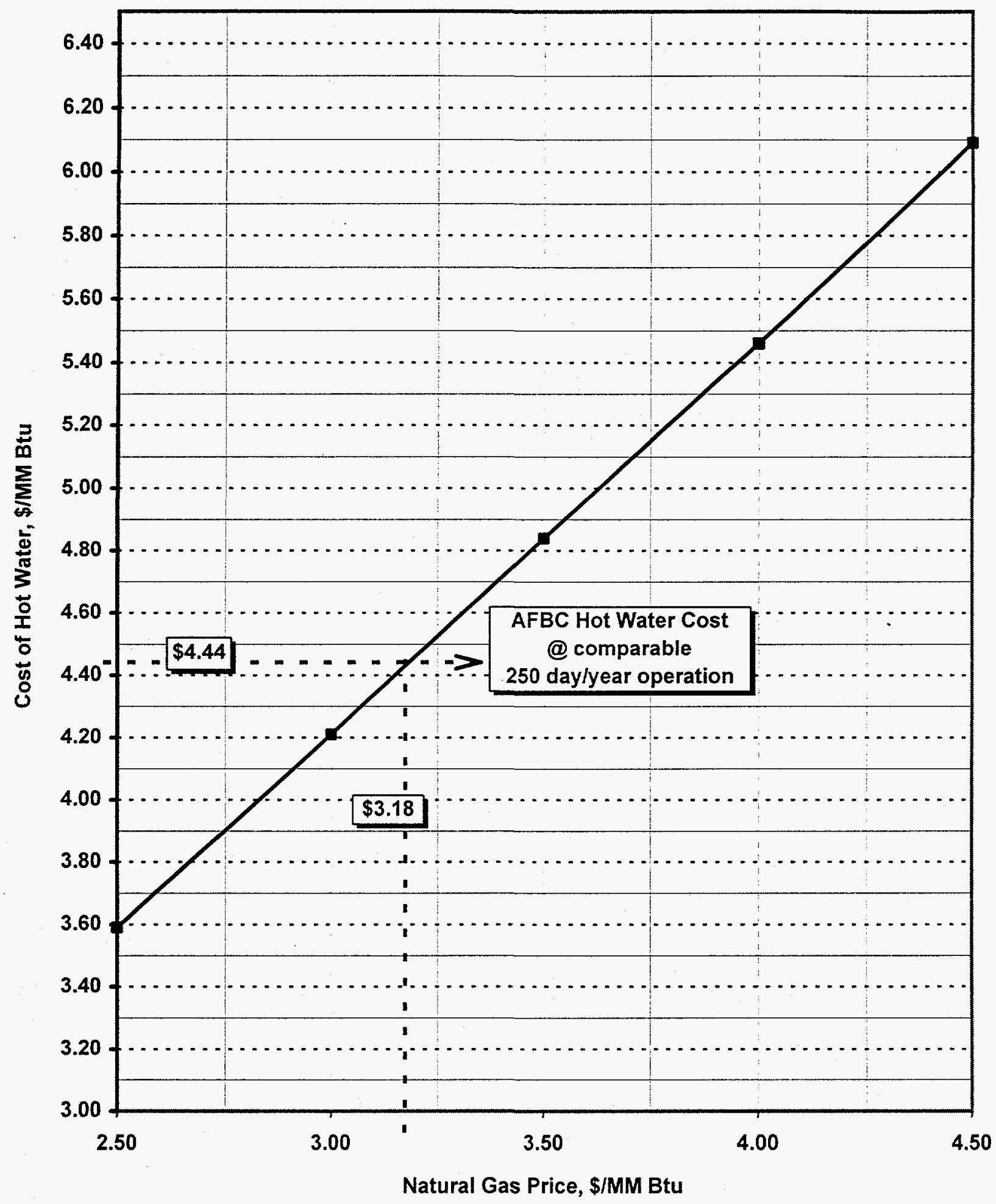

250 day/year operation

Figure 4-4. Natural Gas Hot Water Cost 


\subsection{MARKETS}

In all states that have high sulfur coal reserves, the coal industry has seen a dramatic negative impact on coal consumption because of the ever increasing environmental constraints imposed on the industries burning these coals. This negative impact has been very dramatic in the industrial/commercial marketplace. For instance, according to the 1994 State Energy Data Report, from 1970 to 1994, annual coal use in Ohio by commercial and industrial entities has dropped from 30.9 million tons in 1970 to 7.2 million tons in 1994, a $77 \%$ decrease. To reverse this trend and place coal once again as the fuel of choice, low cost environmentally acceptable technologies must be developed.

The AFBC system that was developed under sponsorship by the U.S. DOE and OCDO is a system that has the potential to reverse the trend toward ever increasing use of natural gas at the expense of the coal industry. The AFBC is a simple design and easy to operate system that lends itself to modular construction, allowing for lower cost shop fabrication as opposed to field fabrication. This AFBC system can process run of mine coal of any ash, moisture or sulfur content. It is amenable for use with all types of coal. It uses low cost limestone, which is abundant in the State of Ohio, as a sorbent to meet the regulatory limits on $\mathrm{SO}_{2}$ emissions. Whereas for coal-fired units less than 100 million Btu/hr there is no Federal limit for $\mathrm{NO}_{\mathrm{x}}$ emissions, the AFBC incorporates a flue gas recycle technique which can be used to reduce $\mathrm{NO}_{\mathrm{x}}$ emissions and it also increases the overall thermal efficiency of the system.

The successful development and widespread implementation of this system, could well start to reverse the trend of decreasing coal use by the commercial, industrial, and institutional market sectors. With the widespread use of this technology, other benefits will arise in the form of increased business revenues from the sale of indigenous limestone, the reduction in fuel costs for the end user which will make its products more cost competitive, and the development of a new technology that will be fabricated and marketed in the United States.

The State Energy Data Report of 1994, showed an annual energy consumption by the Ohio industrial/commercial market sector of $547 \times 10^{12}$ Btu. Based on a U.S. EPA study, commercial /industrial boilers in the U.S. in the size range of 7.3 to 29.3 million Btu/hr make up some $25 \%$ of the total energy consumed by the industrial/commercial market sector. Applying this percentage of energy consumption to the State of Ohio, in 1994 it was estimated that boilers in 
the above size range consumed about $137 \times 10^{12}$ Btu/year. The AFBC developed under this program is suitably applied to boilers in this size range. Assuming that coal fired AFBC units could take $10 \%$ of the 1994 energy market share away from oil and gas by the year 2010, Ohio coal consumption would increase by 550,000 tons/year. To accomplish this increase in market share would require the installation of some $225-10 \times 10^{6} \mathrm{Btu} / \mathrm{hr}$ AFBC units (@70\% capacity factors). The coal consumed by these AFBC units would equate to approximately $7.5 \%$ of the coal consumed by the Ohio commercial/industrial market sector in 1994.

In addition to the use of the AFBC for production of hot water and steam, Will-Burt and EER are evaluating its use for co-generating electrical power and producing hot water or steam for district heating/cooling and/or industrial use. A power generation design based on a hot air Brayton cycle has been developed that can yield, electric-power-out to fuel-in efficiencies of 2025\% (see ASME papers in Appendix). The coal-fired AFBC Brayton cycle is cost competitive with diesel-fired electrical generators in certain locales.

A marketing strategy for the technology is in place. The Will-Burt Company is the team member who will fabricate and market the technology. Will-Burt is currently marketing and fabricating small scale coal fired stokers for industrial, commercial, and institutional use. The AFBC system will be added to its market line as a replacement for the stoker technology. This technology will readily comply with all facets of the Federal Clean Air Act Amendments of 1990. The development team is very enthusiastic about the potential of this technology and is looking forward to the successful commercialization of the AFBC system. 


\subsection{BUDGET SUMMATION}

The overall cost of the Cedar Lane Farms prototype AFBC development program was $\$ 841,714$. The Ohio Coal Development Office funded $\$ 410,798$ or $48.80 \%$ of the program cost. The development team of EER, the Will-Burt Company, the U.S. DOE, OARDC, and Cedar Lane Farms funded $\$ 430,916$ or $51.2 \%$ of the program cost. This compares to the cost proposal included as part of the grant agreement with OCDO for a total project cost of $\$ 825,322$ wherein OCDO agreed to fund $\$ 410,798(49.77 \%)$ with the development team funding $\$ 414,524$ (50.23\%). A breakdown of the program costs is shown in Table 5-1.

\section{TABLE 5-1. Budget Summation}

\begin{tabular}{|l|c|c|r|r||}
\hline \multicolumn{1}{|c|}{ Funding Sponsor: } & OCDO & EER Team & U.S. DOE & Total \\
\hline Personnel & $\$ 68,429$ & $\$ 120,046$ & $\$ 22,700$ & $\$ 211,175$ \\
\hline Equipment & $\$ 29,040$ & $\$ 152,598$ & $\$ 1,700$ & $\$ 183,338$ \\
\hline Supplies & $\$ 75,148$ & $\$ 22,897$ & $\$ 2,500$ & $\$ 100,545$ \\
\hline Contractual & $\$ 90,561$ & $\$ 14,440$ & $\$ 10,000$ & $\$ 115,001$ \\
\hline Travel & $\$ 0$ & $\$ 5,138$ & $\$ 815$ & $\$ 5,953$ \\
\hline Indirect Charges & $\$ 147,620$ & $\$ 50,065$ & $\$ 28,017$ & $\$ 225,702$ \\
\hline Total Project Cost & $\$ \mathbf{4 1 0 , 7 9 8}$ & $\mathbf{\$ 3 6 5 , 1 8 4}$ & $\$ \mathbf{6 5 , 7 3 2}$ & $\$ \mathbf{8 4 1 , 7 1 4}$ \\
\hline
\end{tabular}




\section{APPENDIX}

\section{Technical Papers:}

Small Scale AFBC Hot Air Gas Turbine Power Cycle Presented at the 13th International FBC Conference Orlando, Florida May 7-10, 1995

Environmental Performance of Air Staged Combustor with Flue Gas Recirculation to Burn Coal/Biomass Presented at the 1995 ASAE Annual International Meeting Chicago, Illinois June 18-23, 1995

AFBC - Operation of Small Scale Demonstration for Greenhouse Heating Presented at Power-Gen International '96 Conference Orlando, Florida December 4-6, 1996

AFBC- HAGT, an Efficient Small Scale Power Plant To be presented at the 14th International FBC Conference Vancouver, BC May 11-14, 1997

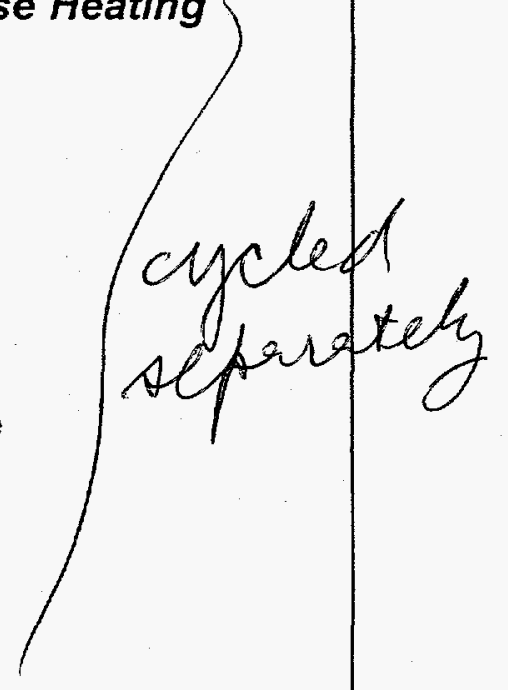

